\title{
Access to Abortion in Cases of Fatal Fetal Abnormality: A New Direction for the European Court of Human Rights?
}

\author{
Bríd Ní GHRÁINNE (Masaryk University) \\ and Aisling MCMAHON (Maynooth University)
}

This is the pre-peer reviewed version of the following article: 'Access to Abortion in Cases of Fatal Fetal Abnormality: A New Direction for the European Court of Human Rights? (2019) 19(3) Human Rights Law Review 561, which has been published in final form at https://doi.org/10.1093/hrlr/ngz020

\begin{abstract}
In contrast to the UN Human Rights Committee (HRComm), the European Court of Human Rights (ECtHR) has not yet found that a prohibition of abortion in cases of fatal fetal abnormality (FFA) violates the prohibition of torture or inhuman and degrading treatment (Art 3 ECHR). We argue that the ECtHR is on the verge of aligning itself with the HRComm because: (i) recent ECtHR jurisprudence is broadening its interpretation of rights within the abortion context; (ii) the ECtHR frequently uses international law as an interpretative tool; and (iii) moving in the direction of the HRComm would not be as controversial as it may have been in the past. More broadly, we take a positive view of fragmentation and demonstrate how an international court, with some ingenuity, can broaden its approach on sensitive topics, by engaging with views of other international courts or Treaty Monitoring Bodies.
\end{abstract}

KEYWORDS: abortion, fatal fetal abnormality, human rights, fragmentation, European Court of Human Rights, Human Rights Committee.

\section{INTRODUCTION}

The European Court of Human Rights' (ECtHR) record on access to abortion is largely one of avoidance. Rather than bolstering access to reproductive rights, the ECtHR has tended to avoid direct encroachment on States' discretion by finding that the respective cases do not meet the Article 3 threshold (prohibition of torture or inhuman or degrading treatment) of the European Convention on Human Rights (ECHR). It has also held that States enjoy a wide margin of appreciation in relation to Article 8 (right to private and family life) and has only found violations of Article 8 where abortion was provided for in domestic law but not accessible in practice. ${ }^{1}$ Unsurprisingly, the dominant position in the literature is that the ECtHR is not a fruitful avenue to challenge a State's prohibition of abortion. ${ }^{2}$

\footnotetext{
${ }^{1}$ See, for example, Tysiq̨ $v$ Poland App No 5410/03 (ECHR 20 March 2007) and A, B and C v Ireland App No 25579/05 (ECHR 16 December 2010).

2 F De Londras, 'Fatal Fetal Abnormality, Irish Constitutional Law, and Mellet v Ireland' (2016) 24(4) Medical Law Review 591; D Fenwick, "'Abortion jurisprudence" at Strasbourg: deferential, avoidant and
} 
This article rejects this view and argues that Article 3 holds significant potential to challenge restrictive abortion regimes. Our analysis seeks to break new ground by showing how the ECtHR's jurisprudence on Article 3 is incrementally developing in favour of broader access to abortion. In our view, recent cases have paid less heed to whether abortion is legally available within States, have focused on the vulnerability and suffering of the respective applicant(s), and have taken an approach that aligns with the absolute nature of Article 3. The ECtHR has not yet explicitly found a violation of Article 3 in respect of a State where abortion is illegal, but we advocate that the time has come for the ECtHR to do so. The tipping point for the ECtHR to do so is provided by recent views of the UN Human Rights Committee (HRComm) ${ }^{3}$ in Mellet $v$ Ireland and Whelan $v$ Ireland, ${ }^{4}$ which found that Article 7 of the 1966 International Covenant on Civil and Political Rights (ICCPR) ${ }^{5}$ (which mirrors Article 3 ECHR) provides for a right to abortion in circumstances of fatal fetal abnormality (FFA). We take a positive view of fragmentation and argue that the ECtHR should align itself with the views of the HRComm because the views of the HRComm appropriately recognise the suffering experienced in such circumstances; because they represent an incremental rather than significant departure from the ECtHR's previous jurisprudence; and because the ECtHR regularly relies on sources of international law. Although encouraging dialogue between international courts/ Treaty Monitoring Bodies (TMBs) ${ }^{6}$ is not without its shortcomings, we argue that it can lead to more rigorous decision-making, it enhances the legitimacy of their decisions, and 'is the essence of the idea (and ideal) of a global 'community of law.'"7 In making this argument, we show how the minimal threshold for Article 3 of the ECHR has the potential to be developed over time both in response to internal shifts in thinking within the ECtHR, and also in response to external influences such as developing trends in other treaty regimes, including the HRComm context.

The arguments made in this piece therefore aim to shift the direction of the ECtHR in future cases; and more generally, they have the potential to support the ECtHR's reliance on international law sources. Moreover, although the main contribution of the

normatively neutral?' (2014) 34(2) Legal Studies 214; D Fenwick, 'The modern abortion jurisprudence under Article 8 of the European Convention on Human Rights' (2012) 12(3-4) Medical Law International 249.

3 The HRComm is a quasi-judicial international committee of independent experts that monitors the implementation of the ICCPR by its States Parties. The HRComm was established by Art 28 of the ICCPR. It can receive communications from individuals against States Parties to the First Optional Protocol (pursuant to Art 1 of Optional Protocol 1) and the HRComm can forward its 'views' to the State Party concerned and to the individual. These views are not binding. However, as the members of the HRComm are experts in international law, and as they are interpreting the ICCPR itself, their views are highly persuasive and are seen as authoritative interpretations of the ICCPR. Art 38(1)(d) of the Charter of the United Nations and Statute of the International Court of Justice 1 UNTS 16 also provides that the views of experts are a subsidiary source of international law.

${ }^{4}$ Human Rights Committee, Siobhán Whelan v Ireland, 12 June 2017, UN Doc CCPR/C/119/D/2425/2014; Human Rights Committee, Amanda Jane Mellet v Ireland, 9 June 2016, UN Doc CCPR/C/116/D/2324/2013. 51966 International Covenant on Civil and Political Rights 999 UNTS 171.

6 The human rights treaty monitoring bodies (TMBs) are committees of independent experts that monitor implementation of the core international human rights treaties. There are ten human rights treaty bodies which are composed of independent experts of recognized competence in human rights. This article focuses on the Human Rights Committee, which monitors the implementation of the 1966 International Covenant on Civil and Political Rights.

${ }^{7}$ LR Helfer and AM Slaughter, 'Toward a Theory of Effective Supranational Adjudication' (1997) 107 Yale Law Journal 273, 325-326. 
paper is to illustrate how international courts and TMBs can and should engage with each other within a global human rights system, the paper also maps how Art 3 could be interpreted in relation to abortion access generally. Hence, the significance of the arguments raised in this piece are heightened by current developments in various domestic contexts. On 25 May 2018, the Irish electorate voted to repeal Art 40.3.3 of the Irish Constitution (which enshrined protection for the unborn) and to replace it with a provision allowing the Oireachtas (Irish Parliament) to legislate to provide abortion services. At the time of writing, legislation has been put before the Oireachtas and abortion services are expected to be available in Ireland in January 2018. ${ }^{8}$ The UK Supreme Court (UKSC) also found in June 2018 that Northern Irish law was incompatible with Art. 8 ECHR for failing to provide access to abortion in cases of rape, incest and FFA, and needed reconsideration. There were split views on whether this was also in violation of Art 3 ECHR, with two members of the court finding it was. However, the UKSC did not make a declaration of incompatibility, ${ }^{9}$ and so far, there has also been no change of Northern Irish law to provide abortion access in such circumstances. ${ }^{10}$ Furthermore, in Poland, attempts to restrict abortion access were abandoned in 2016 following national protests. ${ }^{11}$ These developments demonstrate demands for and moves towards broader rights to abortion access in States with the most restrictive abortion regimes in Europe. All of these States are all bound by both the ECtHR and ICCPR, ${ }^{12}$ and have an obligation to bring their domestic law in line with both treaties. ${ }^{13}$ This article illustrates how the positions of the ECtHR and ICCPR on abortion rights could be aligned, thus giving direction to such States on how to bring their legislation in line with both treaties.

The significance of this alignment extends beyond the matter of abortion and Article 3. Abortion access is a controversial issue, involving complex cultural, religious, political, and legal arguments. It thus forms an excellent case study to demonstrate how an international court, with some ingenuity, can broaden its approach on sensitive topics while maintaining State support. We argue that fragmentation in international law can have positive effects, and one such benefit is the potential for cross-fertilization of norms, where TMBs/international courts cite and/or adopt and/or build on each other's views. ${ }^{14}$ By engaging in cross-fertilization of norms, incremental steps towards new

\footnotetext{
${ }^{8}$ Abortion services should be set up by the new year, Harris says, (Irish Examiner, 27th September, 2018)

${ }^{9}$ This was because because the Court found that the Northern Irish Human Rights Commission did not have legal standing to bring the case.

10 Nonetheless, pressure continues, at the time of writing, Sarah Ewart has sought leave to apply for judicial review seeking a declaration of incompatibly of Northern Irish law with human rights law for failing to provide abortion in cases of FFA. See Fresh legal challenge against abortion laws in North is mounted (Irish Times, 1st October 2018)

https://www.irishtimes.com/news/crime-and-law/fresh-legal-challenge-against-abortion-laws-in-northis-mounted-1.3647745

${ }^{11} \mathrm{C}$ Davies, 'Poland's abortion ban proposal near collapse after mass protests' (The Guardian, 5 October 2016) <https://www.theguardian.com/world/2016/oct/05/polish-government-performs-u-turn-ontotal-abortion-ban> accessed 27 February 2018.

${ }^{12}$ Not all States Parties to the ICCPR are parties to Optional Protocol 1 of the ICCPR, which recognises the competence of the HRComm to receive and consider complaints from individuals. Nonetheless, the authority of the HRComm to provide authoritative interpretations of the ICCPR stems from the ICCPR itself, to which most states in the world are party. See, International Covenant on Civil and Political Rights 991 UNTS 171 (ICCPR).

${ }^{13}$ Art 27, Vienna Convention on the Law of Treaties 1155 UNTS 331 (VCLT).

${ }^{14}$ AM Slaughter, 'A Global Community of Courts' (2003) 44(1) Harvard International Law Journal 191.
} 
interpretations of rights can be developed at a quicker pace. Such cross-fertilisation of norms can complement the enforcement of rights as States may feel more pressure to implement a particular judgment/view if it reflects a broader trend in international law. ${ }^{15}$ More generally, we argue that fragmentation of international law encourages a more rigorous development of rights, as it provides different fora for rights development, and by engaging with other TMBs/international courts, actors are exposed to a greater diversity of perspectives and insights which help to inform their decision-making.

The paper is structured as follows: Section II demonstrates how, on balance, fragmentation is a positive aspect of international law as it provides the opportunity for TMBs/international courts to cross-refer to each other's views/judgments. This process can be used to bolster views/judgments of TMBs/international courts and move them away from patterns of restraint to more emboldened decisions. Section III then introduces the case study of this piece: Article 3 and the ECtHR's jurisprudence on abortion. It aims to show the reticence of the ECtHR in early cases to find a violation of Article 3 and how the approach of the ECtHR has broadened in the recent cases of R.R. $v$ Poland and $P$ and $S$ $v$ Poland. It argues that these cases carve a path for the ECtHR to take a broader stance in future cases concerning abortion rights. Section IV examines the broader approach of the HRComm in Mellet and Whelan, and seeks to demonstrate how these views could act as a tipping point for the ECtHR to find that Art 3 ECtHR provides for a right to abortion in cases of FFA. ${ }^{16}$ Section $V$ puts forwards multiple arguments for why the ECtHR should engage with and adopt the views of the HRComm. The article concludes in Section VI by underlining the significance of cross-fertilisation of norms across the ICCPR and ECHR regimes, by presenting such cross-fertilisation as an essential element of a global system of human rights protection, and by illustrating the importance of these arguments for the development of reproductive rights and their potential broader applicability in other contexts.

\section{FRAGMENTATION AND INTERNATIONAL LAW: THE NECESSITY OF DIALOGUE AND CROSS-FERTILISATION OF NORMS}

Fragmentation refers to the potential for differences in the interpretation of similar legal rules across different treaty regimes. It is particularly evident in human rights law, where there are multiple different treaties with similarly worded content. For example, the ECHR, ${ }^{17}$ ICCPR, ${ }^{18}$ and the Convention on the Rights of the Child (CRC) all prohibit cruel, inhuman and degrading treatment. ${ }^{19}$ They also prohibit discrimination; ${ }^{20}$ and provide for

\footnotetext{
15 S Dothan, 'How International Tribunals Enhance Their Legitimacy' (2013) 14(2) Theoretical Inquires in Law 455, 471; S Dothan 'Judicial Tactics in the European Court of Human Rights' (2011) 12(1) Chicago Journal of International Law 115.

16 Although this paper focuses on abortion and FFA, our arguments are not necessarily limited to that context. Rather we argue that the clearest case for a breach of Art 3 can be made in cases of FFA because of because of the clear fit of such women with the way vulnerability has been construed by the ECtHR and the HRComm to date.

17 Art 3, European Convention on Human Rights 213 UNTS 221.

${ }^{18}$ Art 7, International Covenant on Civil and Political Rights 991 UNTS 171 (ICCPR).

${ }^{19}$ Art 37 and Art 39, Convention on the Rights of the Child 1577 UNTS 3 (CRC).

${ }^{20}$ Art 14 ECHR; Art 21989 Convention on the Rights of the Child 1577 UNTS 3 (CRC); Art 26 ICCPR. See also Art 2 International Covenant on Economic, Social and Cultural Rights 993 UNTS 3 (ICESCR).
} 
the right to private and family life. ${ }^{21}$ All of these rights have been relied upon in the context of abortion access. ${ }^{22}$

However, differences may arise in relation to how TMBs/international courts interpret these rights for various reasons. First, the interpretative approach of each $\mathrm{TMB} /$ international court is influenced by the object and purpose of the treaty which it is tasked to monitor. ${ }^{23}$ For example, the purpose of the CRC is to protect the human rights of children all over the world and the purpose of the CEDAW is to protect the human rights of women all over the world, ${ }^{24}$ whereas the purpose of the ECHR is to protect the human rights of all individuals in Europe. ${ }^{25}$ Second, the mandate and/or jurisdiction of each TMB/international court is likely to differ. For example, the HRComm may give its nonbinding views on a complaint, whereas the ECtHR may issue binding judgments. Third, the circumstances which come before the TMB/international court are likely to differ. Fourth, a particular TMB/international court may have more developed jurisprudence on a particular right or in a particular context simply because more complaints pertaining to these rights/ contexts have come before it. Fifth, and relatedly, a TMB/international court may have less developed jurisprudence on a particular right/context simply because it has not had an opportunity to examine it.

Fragmentation within international law is likely to increase due to its expanding list of international treaties, the increasing proliferation of courts and TMBs with overlapping Contracting States and/or functions, and the lack of hierarchy between TMBs/international courts. Although the increasing rate of fragmentation is widely acknowledged, views are divided on its desirability. ${ }^{26}$ Some authors have praised fragmentation's scope to foster a diversity of voices and its potential to strengthen international law through the proliferation of rules and regimes. ${ }^{27}$ However, more frequently, fragmentation is the subject of criticism. ${ }^{28}$ For example, it is seen as creating

\footnotetext{
${ }^{21}$ Art 8 ECHR, Art 16 CRC, Art 17 ICCPR.

${ }^{22}$ Human Rights Committee, Siobhán Whelan v Ireland, 12 June 2017, UN Doc CCPR/C/119/D/2425/2014; ICCPR Human Rights Committee, Amanda Jane Mellet $v$ Ireland, 9 June 2016, UN Doc CCPR/C/116/D/2324/2013; Tysiac v Poland App No 5410/03 (ECHR 20 March 2007); A, B and C v Ireland App No 25579/05 (ECHR 16 December 2010); R. R. v Poland App No 27617/04 (ECHR, 26 May 2011); P. and S. $v$ Poland App No 57375/08 (ECHR, 30 October 2012).

${ }^{23}$ Art 31(1) VCLT states: 'A treaty shall be interpreted in good faith in accordance with the ordinary meaning to be given to the terms of the treaty in their context and in the light of its object and purpose.'

${ }^{24}$ Preamble, Convention on the Elimination of All Forms of Discrimination Against Women 1249 UNTS 13 (CEDAW).

25 Preamble, ECHR.

${ }^{26}$ International Law Commission, 'Fragmentation of International Law: Difficulties Arising from the Diversification and Expansion of International Law', 13 April 2006, UN Doc A/CN.4/L.682, para 9.

${ }^{27}$ See generally: J Charney, 'Is International Law Threatened by Multiple International Tribunals?' (1998) 271 Recueil des Cours 101; S Kirchner, 'Relative Normativity and the Constitutional Dimension of International Law: A Place for Values in the International Legal System?' (2004) 5(1) German Law Journal 47; B Simma, 'Fragmentation in a Positive Light' (2004) 25 Mich. J. Int'l L. 845. For a discussion of the influences courts can have on each other see: N Miller, 'An International Jurisprudence? The Operation of "Precedent" Across International Tribunals' (2002) 15(3) Leiden Journal of International Law 483; E Voeten, 'Borrowing and Non-Borrowing among International Courts' (2010) 39(2) Journal of Legal Studies, 547.

28 A Fischer-Lescano and G Teubner, 'Regime-Collisions: The Vain Search for Legal Unity in the Fragmentation of Global Law' (2004) 25(4) Mich J Int'l L 999; G Hafner, 'The Risk Ensuing from Fragmentation of International Law', in Report of the International Law Commission on its 52nd Session, (U.N. GAOR, 55th Sess., Suppl. 10, 2000) 321, U.N. Doc. No. ILC(LII)/WG/LT/INFORMAL/2.; G Hafner, 'Pros and Cons Ensuing from Fragmentation of International Law' (2004) 25 Michigan Journal of International
} 
confusion and uncertainty, threatening the unity of international law, and increasing the potential for forum shopping.

In this paper, we use the example of abortion rights in circumstances of FFA to demonstrate that despite having shortcomings, fragmentation, on balance, is a useful feature of international law. The diversification of voices arising from fragmentation provides TMBs/international courts with the opportunity to engage in trans-institutional dialogue (where international courts/TMBs engage with either others' views); and, relatedly, to engage in the cross-fertilization of norms. This is beneficial for three reasons. First, although the proliferation of views/judgments from many TMBs/international courts can lead to confusion because the application of similarly worded rights may differ or appear to differ across treaty regimes, this wealth of jurisprudence can also contribute to a more rigorous development of rights if TMBs/international courts engage in transinstitutional dialogue and cross fertilisation of norms. Comparative lawyers have long pointed out that looking at the experience of other courts teaches judges something they may not have previously known or allows them see an issue in a different light; and, it often provides a greater range of experiences and ideas which leads to better, more rigorous views/judgments. ${ }^{29}$ However, insufficient attention has been paid to the extent to which similar considerations apply to different TMBs/international courts considering issues of international law.

In addition, although TMBs/international courts are not formally bound by each other's views/judgments, they have a role in furthering the shared objective of rights development within a global community. ${ }^{30}$ This objective is obviously considerably furthered if they use the experiences of other TMBs/international courts as a heuristic resource in exploring the range of normative issues at stake in relation to a particular right. Accordingly, provided international courts/TMBs make it clear that they perceive the views of other bodies as persuasive rather than binding, judicial dialogue and crossfertilisation of norms across international rights regimes should be actively encouraged because it complements the fact that 'all human rights are universal, indivisible and interdependent and interrelated.' ${ }^{31}$ As noted by the International Law Commission:

all international law exists in a systemic relationship with other law... although a tribunal may only have jurisdiction in regard to a particular instrument, it must always interpret and apply that instrument in its relationship to its normative environment - that is to say "other" international law. ${ }^{32}$

\footnotetext{
Law 849; ILC, 'Conclusions of the work of the Study Group on the Fragmentation of International Law: Difficulties arising from the Diversification and Expansion of International Law' Yearbook of the International Law Commission: Part 2 (2006) [251] (UN Doc. A/CN.4/SER.A/2006/Add.1 Part 2); A O'Donoghue, Constitutionalism in Global Constitutionalisation (Cambridge University Press 2014) 96.

${ }^{29}$ AM Slaughter, 'A Global Community of Courts, (2003) 44(1) Harvard International Law Journal 191, 201; L Helfer and AM Slaughter, 'Toward a Theory of Effective Supranational Adjudication' (1997) 107 Yale Law Journal 273.

${ }^{30}$ L Helfer and AM Slaughter, 'Toward a Theory of Effective Supranational Adjudication' (1997) 107 Yale Law Journal 273.

${ }^{31}$ AM Slaughter, 'A Global Community of Courts' (2003) 44(1) Harvard International Law Journal 191.

${ }^{32}$ ILC, 'Fragmentation of International Law: Difficulties Arising from the Diversification and Expansion of International Law', 13 April 2006, UN Doc A/CN.4/L.682 [423] (emphasis in original).
} 
This rule finds expression in Article 31(3)(c) of the 1969 Vienna Convention on the Law of Treaties (VCLT), referred to as the 'master key' to the house of international law. ${ }^{33}$ It states that treaty interpretation must take account of 'any relevant rules of international law applicable in the relations between the parties'. This rule provides an explicit doctrinal authority for the cross-fertilisation of norms across systems, and implies that divergence across systems should be appropriately justified to ensure the system of international human rights protection operates effectively as a whole. ${ }^{34}$ As set out below, Article 31(3)(c) has been explicitly referred to by the ECtHR on numerous occasions to justify its reliance on international sources.

Secondly, cross-fertilization of law across different treaty regimes can lead to a system of rights which can be more responsive to societal and/or technological developments. It allows rights to develop at a quicker pace, as more than one body can consider the application of similarly worded provisions and whether these apply in new contexts. It also means that complaints may be considered within different contexts and thus may be informed by different viewpoints. For instance, the general application of a right may be considered by the HRComm (in relation to the ICCPR) or the ECtHR, but other bodies like the Committee on the Rights of the Child or Committee on the Elimination of Discrimination against Women would consider it from the point the of view of children and women, respectively. Although this has the potential to lead to conflicting views/judgments, in practice, instances of conflict occur relatively rarely. ${ }^{35}$ Moreover, such conflict can be avoided if TMBs/international courts pay attention to and engage with what is happening before different fora. In doing so, TMBs/international courts also open themselves to perspectives that might not necessarily have come before them otherwise. This is because the actors articulating particular perspectives might not necessarily have appeared in proceedings before another body, for example, whilst gender equality is likely to be raised before CEDAW it is less likely to be raised before the CRC in the same way. Thus, a more holistic view of rights, which represents a much broader range of perspectives and interests, often emerges as a result of the fragmentation of international law.

Third, new interpretations and/or understandings of rights take place on a continuum over time. ${ }^{36}$ Such incremental developments are useful to ensure that TMBs/international courts maintain a good relationship with States. ${ }^{37}$ Fragmentation can complement this process of rights development as incremental steps can occur across different bodies in a global system, which can then refer to each other. ${ }^{38}$ Having more than one TMB/international court interpreting rights allows bodies to use each other's

\footnotetext{
${ }^{33}$ Ms. Xue Hanqin during the debates in the ILC on the significance of article 31 (3) (c) in ILC, 'Fragmentation of International Law: Difficulties Arising from the Diversification and Expansion of International Law', 13 April 2006, UN Doc A/CN.4/L.682 [420].

${ }^{34}$ L Helfer and AM Slaughter, 'Toward a Theory of Effective Supranational Adjudication' (1997) 107 Yale Law Journal 273.

35 M Forowicz, The Reception of International Law in the European Court of Human Rights, (Cambridge University Press 2010.

${ }^{36}$ AM McMahon, 'The Morality Provisions in the European Patent System: An Institutional Examination' (PhD Thesis University of Edinburgh), chapter 5.

${ }^{37}$ L Helfer and AM Slaughter, 'Toward a Theory of Effective Supranational Adjudication' (1997) 107 Yale Law Journal 273, 296.

${ }^{38}$ L Helfer and AM Slaughter, 'Toward a Theory of Effective Supranational Adjudication' (1997) 107 Yale Law Journal 273, 314-315.
} 
interpretations to bolster their own developments. For the reasons outlined below, our article argues that using interpretations of other TMBs/international courts is more effective in maintaining the reputation of a particular TMB/international court with a domestic public than where TMBs/international courts rely solely on incremental developments of its own previous views/ judgments. This type of supra-national crossreferral lends a source of external legitimation. ${ }^{39}$ Moreover, by referring to similar views of another institution, a TMB/international court can justify its views by reference to a broader trend. 40

Such cross-referencing also helps ground interpretations as mandated by international law, and to mitigate what might otherwise be perceived as an illegitimate discretionary interpretation. ${ }^{41}$ In doing so, TMBs/international courts can bolster the legitimacy of their views/judgments because the fact that other bodies have made similar findings lends credibility to the decision. ${ }^{42}$ It is also more difficult for a State to ignore the views/judgments of a TMB/international court if violations of the State's obligations have been found by more than one TMB/international court. Moreover, it makes it more difficult for a State to argue that such decisions are unjustifiable as the TMB/international court cannot be presented as an outlier if it has support in its position from other TMBs/international courts. In addition, if the State fails to comply in such circumstances, the TMBs/international courts can stand together on an interpretation. Hence, it is more likely the TMBs'/international courts' other Contracting States would perceive the State as defiant rather than the TMB/international court as acting unjustifiably. This reduces the reputational risk for TMBs/international courts in criticising States' conduct. ${ }^{43}$ Moreover, TMBs/international courts often act tactically and take slow incremental steps in finding violations of treaties until they feel it has reached a point where States will comply. ${ }^{44}$ However, if other TMBs/international courts have already laid the path for them, it is less likely they will be as cautious and rather than tending towards selfrestraint, they may be more emboldened to act. Put simply, this process of incremental development and cross-fertilization allows TMBs/international courts to tread a delicate balance between, on the one hand, declaring that States have violated international human rights law, and on the other hand, ensuring that in doing so they maintain respect of States. States alone have the ability to implement the views/judgments of TMBs/international courts, and thus their support for these institutions is vital.

As the foregoing analysis has shown, despite fragmentation's shortcomings, we argue on balance that it is a positive feature of the global human rights landscape, as it

\footnotetext{
39 S Dothan, 'How International Tribunals Enhance Their Legitimacy' (2013) 14(2) Theoretical Inquires in Law 455.

${ }^{40}$ L Helfer and AM Slaughter, 'Toward a Theory of Effective Supranational Adjudication' (1997) 107 Yale Law Journal 273, 325.

${ }^{41}$ S Dothan, 'How International Tribunals Enhance Their Legitimacy' (2013) 14(2) Theoretical Inquires in Law 455, 469; S Dothan 'Judicial Tactics in the European Court of Human Rights' (2011) 12(1) Chicago Journal of International Law 115.

${ }^{42}$ S Dothan, 'How International Tribunals Enhance Their Legitimacy' (2013) 14(2) Theoretical Inquires in Law 455.

${ }^{43}$ S Dothan 'Judicial Tactics in the European Court of Human Rights' (2011) 12(1) Chicago Journal of International Law 115.

${ }^{44}$ S Dothan 'Judicial Tactics in the European Court of Human Rights' (2011) 12(1) Chicago Journal of International Law 115; S Dothan, 'How International Tribunals Enhance Their Legitimacy' (2013) 14(2) Theoretical Inquires in Law 455.
} 
provides an opportunity for TMBs/international courts to draw on the experience of the wider community of human rights monitoring and enforcement in working out how to deal with controversial issues that come before it. In the remainder of this article, we develop this argument by considering its implications for the ECtHR's approach to access to abortion in cases of FFA, looking at how engaging with international TMBs views, and specifically, the HRComm, would be useful for the ECtHR in this context.

The development of Art 3 ECHR/Art 7 ICCPR in this context provides an ideal case study for exploring these aspects of fragmentation and the need for judicial dialogue for five reasons. First, the HRComm and ECtHR positions on these articles provide a useful exemplar of fragmentation across regional and international regimes of human rights protection. The position of the HRComm represents the general position in international law that there is a right to access abortion in cases of FFA. ${ }^{45}$ However, this has not yet been considered by the ECtHR and thus no similar recognition is evident in this context. ${ }^{46}$ Second, this area represents a microcosm, with heightened tensions of the type that can generally arise within fragmented international legal spaces. Abortion access is a controversial issue, involving complex cultural, religious, political, and legal arguments. Accordingly, examining this context provides valuable lessons and insights for understanding the usefulness of fragmentation and trans-institutional dialogue for rights development more generally.

Third, as discussed in section III below, Art 3 ECHR and Art 7 ICCPR are worded in an almost identical manner, so one can readily compare interpretations of these from the ECtHR and HRComm. Fourth, there is an established body of HRComm views in Mellet and Whelan expressly finding violations of Art 7 for denial of abortion in cases of FFA, and although no similar factual circumstances have come before the ECtHR, it has decided other cases on Art 3 and abortion access. Hence, the interpretative approach of both bodies to this issue is ascertainable and can be compared. ${ }^{47}$ This allows us to track the development of these rights within both contexts. It also allows us to examine the potential for cross-fertilization should a similar case come before the ECtHR and to demonstrate why in our view the ECtHR should follow the approach of the HRComm.

${ }^{45}$ C Zampas and JM Gher, 'Abortion as a Human Right - International and Regional Standards' (2008) 8(2) Human Rights Law Review 249; RJ Cook and BM Dickens, 'Human Rights Dynamics of Abortion Law Reform' (2003) 25(1) Human Rights Quarterly 1. The position of the HRComm reflects the position of the ICESCR.; the CRC; and the CEDAW. However, the Committee on the Rights of Persons with Disabilities has been critical of this position. See Committee on the Rights of Persons with Disabilities, 'Comments on the Draft General Comment No. 36 of the Human Rights Committee on article 6 of the International Covenant on Civil and Political Rights' (2017) [1] <http://www.ohchr.org/EN/HRBodies/CCPR/Pages/GC36Article6Righttolife.aspx> accessed 27 February 2018. The Committee stated "Laws which explicitly allow for abortion on grounds of impairment violate the Convention on the Rights of Persons with Disabilities (Art,. 4,5,8). Even if the condition is considered fatal, there is still a decision made on the basis of impairment."

46 The case of $D$ v. Ireland, App no 26499/02 (ECHR 27 June 2006) concerned a claim of access to abortion in FFA. However, the ECtHR ruled the complaint was inadmissible as the applicant whose pregnancy suffered a FFA diagnosis, had not exhausted domestic remedies because she did not seek access to abortion in the Irish domestic courts. It held there was an arguable claim for access to abortion in cases of FFA in Ireland as the domestic position was unclear.

${ }^{47}$ There are no cases which have been dealt with by both the HRComm and ECtHR in the abortion context. Indeed, Art 35(2)(b) ECHR states that: "The Court shall not deal with any application submitted under Article 34 that ...(b) is substantially the same as a matter that has already been examined by the Court or has already been submitted to another procedure of international investigation or settlement and contains no relevant new information.' 
Fifth, both treaties protect rights that are primarily civil and political in nature, and are inspired by the Universal Declaration of Human Rights, as well as ideals of peace, freedom, and justice. ${ }^{48}$ This is similar to other human rights regimes, and hence our analysis offers generalizable lessons for the development of human rights in other contexts.

\section{THE EUROPEAN COURT OF HUMAN RIGHTS AND ACCESS TO ABORTION IN CASES OF FATAL FETAL ABNORMALITY: THE ROLE OF ART 3}

This section argues that the ECtHR's interpretation of Art. 3 in the context of abortion is incrementally broadening and illustrates how this area is ripe for cross-fertilisation of norms between the ICCPR and ECHR regimes.

\section{A. The Traditional Approach of the European Court of Human Rights}

As noted, arguments for broadening access to abortion using the ECHR have tended to focus on Art 8 (right to private and family life) and have generally been unsuccessful because of the ECtHR's application of the margin of appreciation. This principle was expounded in detail in the Handyside case:

... it is not possible to find in the domestic law of the various Contracting States a uniform European conception of morals ... By reason of their direct and continuous contact with the vital forces of their countries, State authorities are in principle in a better position than the international judge to give an opinion on the exact content of these requirements as well as on the 'necessity' of a 'restriction' or 'penalty' intended to meet them .... Consequently, Article 10 para. 2 (art 10-2) leaves to the contracting States a margin of appreciation. ${ }^{49}$

Although the margin of appreciation is not generally adopted by other international courts and monitoring bodies, ${ }^{50}$ it is entrenched in the ECtHR's jurisprudence. ${ }^{51}$ Hence an examination of its desirability is a fruitless endeavour and, in any case, beyond the scope of this article. Indeed, the jurisprudence relating to Art 8 and abortion access has been

\footnotetext{
48 Preambles to the ECHR and ICCPR.

${ }^{49}$ Handyside v United Kingdom App no 5493/72 (ECHR, 7 December 1976) [48]. See also H Yourow, The Margin of Appreciation Doctrine in the Dynamics of European Human Rights Jurisprudence (Springer Netherlands 1996) 13. See also, JG Merrills, The Development of International Law by the European Court of Human Rights ( $2^{\text {nd }}$ Ed, Manchester University Press 1995) chapter 7; Janneke Gerards, 'Margin of Appreciation and Incrementalism in the Case-Law of the European Court of Human Rights', (2018) 18(3) Human Rights Law Review 495.

50 The Human Rights Committee has expressly rejected the margin of appreciation. See UN Human Rights Committee 'General comment no. 34, Article 19, Freedoms of opinion and expression' (12 September 2011) UN Doc CCPR/C/GC/34 [36]. At least one decision from the Inter-American Commission on Human Rights and two advisory opinions of the Inter-American Court of Human Rights have made express reference to the 'margin of discretion.' See Inter-American Court of Human Rights Rios Montt v. Guatemala (1993) Case 10.804, Report No. 30/93, OEA/Ser.L/V.85, doc. 9 rev.; Proposed Amendments to the Naturalization Provision of the Constitution of Costa Rica, Advisory Opinion OC-4/84 Inter-American Court of Human Rights Series A No 4 (19 January 1984) [58, 62 and 63] and Rights and guarantees of children in the context of migration and/or in need of international protection, Advisory Opinion OC-21/14, Inter-American Court of Human Rights Series A No.21 (August 19, 2014) [39].

51 Early case law of relevance includes: Lawless v Ireland (1961) 1 EHRR 15; Denmark v. Greece App no. 3321/67, Norway v. Greece App no. 3322/67, Sweden v. Greece App no. 3323/67, Netherlands v. Greece App no. 3344/67 (the 'Greek' case) (Commission Decision, 18 November, 1969); Klass and Others v Germany App no 5029/71 (ECHR, 6 September 1978); Arrowsmith v United Kingdom (1978) 3 EHRR 218.
} 
extensively discussed elsewhere and we do not intend to reopen such arguments here. ${ }^{52}$ Suffice it to say that at present, the only circumstances where the ECtHR will find a violation of Art 8 is where abortion is provided for in domestic law but inaccessible in practice. ${ }^{53}$ Art 8 as currently applied is a futile avenue for applicants unless abortion access is already provided for in the domestic framework.

\section{B. Towards a Broader Interpretation of Article 3 of the European Convention on Human Rights}

Unlike Art 8, Art 3 ECHR protects an absolute right. ${ }^{54}$ It must be upheld even 'in times of war or other public emergency threatening the life of a nation'.55 No margin of appreciation applies, and States cannot justify any limitations or restrictions of rights falling under this Article. Once an act is determined to constitute torture, or inhuman, or degrading treatment, States are held to be in violation of the ECHR. In the words of the European Commission of Human Rights in Ireland $v$ United Kingdom:

It follows that the prohibition under Art 3 of the Convention is an absolute one and that there can never be under the Convention, or under international law, a justification for acts in breach of that provision. ${ }^{56}$

The ECtHR has held on numerous occasions that the alleged ill-treatment must attain a minimum level of severity to fall within the scope of Art 3. The assessment of this threshold is relative and depends on all the circumstances of the case, such as the duration of the treatment and its physical or mental effects and the sex, age and state of health of the victim. ${ }^{57}$ The ECtHR considers treatment to be 'inhuman' when it was 'premeditated, [...] applied for hours at a stretch and caused either actual bodily injury or intense physical or mental suffering'. 58 Treatment is considered to be 'degrading" when it humiliates or

\footnotetext{
52 R Scott. 'Risks, Reasons and Rights: The European Convention on Human Rights and English Abortion Law' (2016) 24(1) Medical Law Review 1; D Fenwick, “'Abortion Jurisprudence” at Strasbourg: Deferential, Avoidant and Normatively Neutral?' (2014) 34 Legal Studies 214; D Fenwick, 'The Modern Abortion Jurisprudence under Article 8 of the European Convention on Human Rights' (2013) 12 Medical Law International 249; C Zampas and JM Gher 'Abortion as a Human Right - International and Regional Standards', (2008) 8(2) Human Rights Law Review 249.

53 Tysiąc v Poland App No 5410/03 (ECHR 20 March 2007); R.R. v Poland App no 27617/04 (ECHR, 26 May 2011); $A, B$ and $C v$ Ireland App No 25579/05 (ECHR 16 December 2010) and the more recent case $P$. and $S$. $v$ Poland App No 57375/08 (ECHR, 30 October 2012).

${ }^{54} \mathrm{~N}$ Mavronicola, 'Is the Prohibition Against Torture and Cruel, Inhuman and Degrading Treatment Absolute in International Human Rights Law? A Reply to Steven Greer' (2017) 17(3) Human Rights Law Review 479; N Mavronicola, 'What Is an Absolute Right: Deciphering Absoluteness in the Context of Article 3 of the European Convention on Human Rights' 12(4) Human Rights Law Review 723; D Feldman, Civil Liberties and Human Rights in England and Wales (2nd edn, Oxford University Press 2002) 242; N Mavronicola, 'Crime, Punishment and Article 3 ECHR: Puzzles and Prospects of Applying an Absolute Right in a Penal Context' (2015) 15(4) Human Rights Law Review 721. For a contrary opinion, see S Greer, 'Is the Prohibition Against Torture, Cruel, Inhuman and Degrading Treatment Really "Absolute” in International Human Rights Law? A Reply to Griffin and Mavronicola' (2018) 18(2) Human Rights Law Review 297; S Greer, 'Is the Prohibition against Torture, Cruel, Inhuman and Degrading Treatment Really 'Absolute' in International Human Rights Law?' (2015) 15(1) Human Rights Law Review 101; S Greer, 'Should Police Threats to Torture Suspects Always be Severely Punished? Reflections on the Gafgen Case' (2011) 11 Human Rights Law Review 67.

${ }_{55}$ Art 15(1) ECHR.

56 Ireland v. United Kingdom App no 5319/71 (ECHR, 1 January 1978).

${ }^{57}$ Kudła v. Poland App no 30210/96 (ECHR, 26 October 2000) [91].

${ }^{58}$ Kudła v. Poland App no 30210/96 (ECtHR, 26 October 2000) [92].
} 
debases an individual, showing a lack of respect for, or diminishing, his or her human dignity, or arouses feelings of fear, anguish or inferiority capable of breaking an individual's moral and physical resistance. ${ }^{59}$ It may suffice that the victim is humiliated in his or her own eyes, even if not in the eyes of others. ${ }^{60}$

The ECHR is a 'living instrument which... must be interpreted in the light of presentday conditions' 61 and this requires the ECtHR to develop its interpretation of the ECHR in response to changing societal and technological developments. Over time, the ECtHR has developed a broader interpretative approach to Art 3, by developing the right beyond the narrow literal interpretation of what was traditionally perceived as falling within the scope of Art 3. More recently, the ECtHR has expanded the application of Art 3 to a broad range of areas including the detention of persons suffering from acute mental-health problems, the suffering of an individual whose deceased relatives' organs were removed without consent, ${ }^{62}$ any recourse to force by law-enforcement officers that is not strictly necessitated by the applicant's conduct, ${ }^{63}$ and the forced sterilization of Roma women. ${ }^{64}$ Moreover, recent cases such as $V v U K$ have established that 'the absence of an intent to debase the victim cannot conclusively rule out the finding of a violation' of Article $3.65 \mathrm{~A}$ similar broadening in the ECtHR's interpretative approach to Article 3 in the context of abortion access in cases of FFA is evident when one examines the case law over time.

\section{Early Article 3 Cases and Access to Abortion: A Narrow Interpretative View}

To date, Article 3 has been raised in four cases before the ECtHR concerning access to abortion namely: Tysiąc v Poland (2007), ${ }^{66}$ A, B, C v Ireland (2010) ${ }^{67}$; R.R. $v$ Poland (2011); ${ }^{68}$ and $P$ and $S v$ Poland (2012). ${ }^{69}$ In all four cases, the ECtHR found a violation of Article 8. Article 3 arguments were unsuccessful in the two earlier decisions but violations of Article 3 were found in the two more recent cases concerning Poland, where the applicants did not have effective access to legally available abortion services. An analysis of these cases demonstrates an incremental broadening in the ECtHR's approach to Article 3 in the abortion context. The key factor for the ECtHR in determining violations of Article 3 is the vulnerability of the applicant which, as will be seen in section IV below, aligns with the way in which Article 7 has been interpreted in the ICCPR context. This suggests a convergence in the interpretative approach to these Articles across the ECHR

\footnotetext{
${ }^{59}$ Kudła v. Poland App no 30210/96 (ECHR, 26 October 2000) [92]; Pretty v. the United Kingdom App no. 2346/02 (ECHR, 29 April 2002) [52].

60 Tyrer v. The United Kingdom App no 5856/72 (ECHR, 15 March 1978) [32].

61 Tyrer v. The United Kingdom App no 5856/72 (ECHR, 15 March 1978) [31]. As cited in: Soering v The United Kingdom App no. 14038/88 (ECHR, 7 July 1989) [102]; Loizidou v Turkey (Preliminary Objections) App no 15318/89 (ECHR, 23 March 1995)[71]; Selmouni v. France App no 25803/94 (ECHR July 28, 1999) [101].

62 Elberte v Latvia App no 61243/08 (ECHR, 13 January 2015).

${ }^{63}$ Bouyid v Belgium App no 23380/09 (ECHR, 28 September 2015); El-Masri v The Former Yugoslav Republic of Macedonia App no 393630/09 (ECHR 13 December, 2012).

${ }^{64}$ V.C. v Slovakia App no. 18968/07 (ECHR, 8 November 2011).

$65 \mathrm{~V} v$ United Kingdom App no. 24888/94 (ECHR, 16 December 1999); T. v. United Kingdom, App no 24724/94 (ECHR, 16 December 1999) [71].

66 Tysiac v Poland App No 5410/03 (ECHR, 20 March 2007).

${ }^{67}$ A, B and C v Ireland App No 25579/05 (ECHR, 16 December 2010); E Wicks, 'A, B, C v Ireland: Abortion Law under the European Convention on Human Rights' (2011) 11(3) Human Rights Law Review 556.

${ }^{68}$ R.R. $v$ Poland App no 27617/04 (ECHR, 26 May 2011)

${ }^{69}$ P. and S. v Poland App No 57375/08 (ECHR, 30 October 2012).
} 
and ICCPR systems.

In both Tysią $v$ Poland (2007) ${ }^{70}$ and $A, B, C v$ Ireland (2010) ${ }^{71}$ the ECtHR dismissed the Article 3 arguments by indicating that the required threshold of Article 3 was not met, but there was little real engagement by the ECtHR with the specific facts in each case. Tysiac related to an applicant who was advised that her retina might detach during pregnancy. ${ }^{72}$ Her repeated requests for abortion on medical grounds were denied. After the baby was born, the applicant was told that she was at risk of going blind. She was also severely disabled and was told that she would need constant care for the rest of her life. Her criminal complaint and disciplinary proceedings against the doctors involved failed. She argued before the ECtHR that her treatment amounted to inhuman and degrading treatment under Article 3 as the State failed to make an abortion available in circumstances which threatened her health. She was forced to continue a pregnancy knowing she would be nearly blind by the time of birth causing her anguish and distress. She also argued that the loss of sight on her family and personal life had a devastating effect. ${ }^{73}$

In response, the ECtHR devoted just three sentences by way of reasoning to the Article 3 ground. It reiterated its case-law on the notion of ill-treatment and the circumstances in which the responsibility of a Contracting State may be engaged, including under Article 3 of the Convention by reason of the failure to provide appropriate medical treatment'. ${ }^{74}$ However, it did not delve into these cases, or engage specifically with how the facts in the applicant's case failed to meet the notion of ill-treatment constituting a breach of Article 3. The one case cited - Illhan v. Turkey - was seven years old and concerned a Kurdish man who was severely beaten by Turkish security forces and was then denied access to medical services for a significant period of time. ${ }^{75}$ This case exemplifies the traditional understanding of an Article 3 violation - involving physical injuries that were inflicted by State actors and the subsequent failure by the State to provide the applicant with appropriate medical care while he was in custody. ${ }^{76}$ However, Article 3 has a far richer jurisprudential history than the ECtHR's passing reference to Illhan implies. Many of the cases described above in section III(B) which expound a broad meaning of the term 'inhuman and degrading treatment' had been decided by the time Tysiac came before the ECtHR. In particular, the ECtHR in Tysiac should have engaged with its case law which found that psychological distress and denial of medical treatment can lead to a violation of Article $3 .{ }^{77}$ It should also have engaged with its then-emerging jurisprudence on the relevance of vulnerability in assessing Article 3 claims. ${ }^{78}$ As will be

\footnotetext{
${ }_{70}$ Tysiąc v Poland App No 5410/03 (ECHR, 20 March 2007)

${ }^{71} A, B$ and $C V$ Ireland App No 25579/05 (ECHR, 16 December 2010).

${ }^{72}$ The ECtHR found a violation of Art 8 by the State in failing to comply with its positive obligations to secure the applicant respect for her private/family life.

${ }^{73}$ Tysiąc v Poland App No 5410/03 (ECHR, 20 March 2007) [65].

${ }^{74}$ Tysiąc v Poland App No 5410/03 (ECHR, 20 March 2007) [66].

75 Îhan v Turkey App no. 22277/93 (ECHR 27 June 2000).

${ }^{76}$ A Zureick, '(En)gendering Suffering: Denial of Abortion as a Form of Cruel, Inhuman, or Degrading Treatment' (2015) 38(1) Fordham International Law Journal 99.

77 Such as Ireland v. United Kingdom App no 5319/71 (ECHR, 1 January 1978); Aydin v Turkey App no 2317/94 (ECHR, 25 September 1997); Dîkme v Turkey App no 20869/92 (ECHR 11 July 2000); Selmouni v. France App no 25803/94 (ECHR July 28, 1999); Soering $v$ The United Kingdom App no. 14038/88 (ECHR, 7 July 1989).

78 See Chapman v United Kingdom App no 27238/95 (ECHR, 18 January 2001) [96]; Connors v United Kingdom App no 66746/01 (ECHR, 27 May 2004) [84].
} 
explained below, this criteria has been subsequently applied by the ECtHR to find a violation of Article 3 in cases where abortion is lawfully available but inaccessible in practice. Instead, the ECtHR in Tysiac simply stated that the circumstances did not disclose a breach of Article 3 as the minimum threshold for such a finding was not met, and stated that the complaint would be more appropriately examined under Article 8 ECHR.

The brevity of the ECtHR's discussion and its failure to cite, let alone discuss, the key cases that could be applicable is particularly disappointing given the ECtHR's long-held position that:

the existence of a risk of ill-treatment in breach of Article 3 [...] must necessarily be a rigorous one in view of the absolute character of this provision and the fact that it enshrines one of the fundamental values of the democratic societies making up the Council of Europe. ${ }^{79}$

We argue that this decision was influenced at least in part by the political sensitivity of the rights at hand. ${ }^{80}$ The ECtHR may have been reluctant to find a violation given it was the first case on abortion discussed under Article 3. If the ECtHR found that the threshold of Article 3 was met, it would have no choice but to find a violation as Article 3 protects an absolute right. This could have been met with backlash from States which the ECtHR may have been loath to avoid. Others have argued on a more general level that the notion of absolute rights is nebulous because it involves an assessment of subjective factors, which allows the ECtHR to use discretion. ${ }^{81}$ The ECtHR has been accused of (mis)using this discretion to avoid finding a violation of Article 3 in other politically sensitive contexts, such as cases involving terrorism, deportation, and socio-economic issues. ${ }^{82} \mathrm{In}$ Tysiac, the ECtHR may have also felt that it did not need to engage with the Article 3 argument as it found a breach under Article 8 and hence the applicant was able to get some relief from the ECtHR.

A similar reticence is evident in terms of Article 3 in $A, B$ and $C v$ Ireland. ${ }^{83}$ In that case, alongside other grounds, ${ }^{84}$ the three applicants argued that the restrictions on

\footnotetext{
${ }^{79}$ Vilvarajah $v$ the United Kingdom App no 13163/87 (ECHR, 30 October 1991).

80 On the influence of political considerations and the ECtHR more generally, see D McGoldrick, 'A Defence of the Margin of Appreciation and an Argument for its Application by the Human Rights Committee' (2016) 65(1) International and Comparative Law Quarterly 21; M Nicholson '(2016) 'Majority rule and human rights : identity and non-identity in SAS v France' (2016) 67(2) Northern Ireland Legal Quarterly 115.

${ }^{81}$ Although Feldman states that obligations under Article 3 are 'absolute, non-derogable and unqualified', he remarks that 'a degree of relativism cannot, in practice, be entirely excluded from the application of the notions of inhuman or degrading treatment.' S Feldman, Civil Liberties and Human Rights in England and Wales (2nd edn, Oxford University Press, 2002) 242 as cited in N Mavronicola, 'What is an 'absolute right'? Deciphering Absoluteness in the Context of Article 3 of the European Convention on Human Rights' (2012) 12(4) Human Rights Law Review 723, 728.

${ }^{82} \mathrm{~F}$ de Londras and K Dzehtsiarou, Great Debates on the European Convention on Human Rights (Palgrave 2018) chapter 4; H Fenwick, 'Post 9/11 UK Counter-Terrorism Cases in the European Court of Human Rights: A 'Dialogic' Approach to Rights' Protection or Appeasement of National Authorities?' in FF Davis and F De Londras (eds) Critical Debates on Counter-Terrorist Judicial Review (Cambridge University Press 2014); V Mantouvalou 'N v UK: No Duty to Rescue the Nearby Needy?' (2009) 72 (5) Modern Law Review 815; B Ní Ghráinne, 'Challenges in the Relationship between Internally Displaced Persons and International Refugee Law' (DPhil thesis, University of Oxford).

${ }^{83} \mathrm{~A}, \mathrm{~B}$ and $\mathrm{C} v$ Ireland App No 25579/05 (ECHR 16 December 2010).

${ }^{84} \mathrm{~A}$ violation of Art 8 was found in respect of applicant $\mathrm{C}$, as although abortion was available under Irish
} 
accessing an abortion in Ireland breached Article 3. Each of the applicants had travelled to the United Kingdom for an abortion: A and B both for health and/or wellbeing reasons, whilst $\mathrm{C}$ feared the pregnancy constituted a risk to her life. On the Article 3 ground, the applicants argued that the criminalisation of abortion was discriminatory (crude stereotyping and prejudice against women), caused an affront to women's dignity and stigmatised women, increasing feelings of anxiety'. 85 The only options open to women maintaining the pregnancy to term or seeking an abortion abroad - 'were degrading and a deliberate affront to their dignity'. ${ }^{86}$ Although it acknowledged that travelling abroad for the purpose of an abortion was physically and psychologically arduous for all three applicants, ${ }^{87}$ and financially burdensome for the first applicant, ${ }^{88}$ the ECtHR stated that the applicants' circumstances did not meet the level of severity falling within the scope of Article 3.89 Again, the ECtHR offered no real engagement with the applicants' circumstances or any explanation of why these did not meet the Article 3 threshold.

It is particularly worrisome that the ECtHR did not engage with the facts in C's case, in which it accepted there was a risk to life. $C$ had undergone three years of chemotherapy for a rare form of cancer. Her doctor advised her that it was not possible to predict the effect of pregnancy on her cancer and that it would be dangerous for the fetus if she were to have chemotherapy during the first trimester. When she discovered she was pregnant, she received insufficient information from medical professionals as to the impact of the pregnancy on her health and life and the impact of her prior tests for cancer on the fetus. Given the uncertainty about the risks involved, $C$ travelled to the United Kingdom for an abortion. She maintained that she wanted a medical abortion (drug-induced miscarriage) as her pregnancy was at an early stage. However, she could not find a clinic that would provide this treatment, as she was not a resident of the United Kingdom. She had to wait a further eight weeks until a surgical abortion was possible. On returning to Ireland after the abortion, $\mathrm{C}$ suffered complications due to an incomplete abortion, including prolonged bleeding and infection.

The evidence in the case demonstrated that C's circumstances involved physical and mental suffering. As it had done in many previous cases, ${ }^{90}$ the ECtHR accepted that these factors were relevant in assessing Article 3 violations. However, like Tysiac, the ECtHR did not engage with the facts at hand and did not give specific reasons as to why the Article 3 threshold was not met. For the same reasons we set out in respect of Tysiac, above, $A, B$, and $C$ was arguably also motivated, at least in part, by considerations flowing from the sensitive nature of abortion rights. Moreover, the ECtHR may have been particularly reticent to find a violation in this case because at that time, Ireland's framework on abortion was one of the most restrictive in Europe and the previous domestic and international case law concerning abortion rights in Ireland had sparked significant

\footnotetext{
law when a woman's life was at risk, the avenues for ascertaining entitlement were not clear.

${ }^{85} A, B$ and $C$ v Ireland App No 25579/05 (ECHR, 16 December 2010) [162].

${ }^{86} A, B$ and $C$ v Ireland App No 25579/05 (ECHR, 16 December 2010) [162].

${ }^{87} A, B$ and $C$ v Ireland App No 25579/05 (ECHR, 16 December 2010) [124-127].

${ }^{88} A, B$ and $C$ v Ireland App No 25579/05 (ECHR, 16 December 2010) [128] and [163].

${ }^{89} A, B$ and $C$ v Ireland App No 25579/05 (ECHR, 16 December 2010) [165].

${ }^{90}$ For example, Kudła v. Poland App no 30210/96 (ECHR, 26 October 2000) [91]; Ireland v. United Kingdom App no 5319/71 (ECHR, 1 January 1978) [162]; Denmark v. Greece App no. 3321/67, Norway v. Greece App no. 3322/67, Sweden v. Greece App no. 3323/67, Netherlands v. Greece App no. 3344/67 (the 'Greek' case) (Commission Decision, 18 November, 1969)
} 
controversy. ${ }^{91}$ Nonetheless, as a matter of strict interpretation of law, given that Article 3 contains an absolute right, such considerations should not have formed a part of the ECtHR's assessment under this provision.

Despite $A, B$, and $C^{\prime}$ s lack of reasoning on Article 3, two final points can be gleaned from the judgment as a whole which are relevant for the purposes of this study. First, the act of having to travel abroad to avail of an abortion does not, in itself, constitute a breach of the ECHR. Rather it is one factor to be taken into account in conjunction with the broader circumstances at hand. Second, the ECtHR did not rule out that the threshold of Article 3 could be established in future cases in which abortion was denied.

\section{Recent Article 3 Cases and Access to Abortion - A Broader Interpretative View?}

This was precisely what happened in the more recent decisions of $R . R . v$ Poland, ${ }^{92}$ and $P$. and $S . v$ Poland. ${ }^{93}$ In both cases the ECtHR found a breach of Article 3. These cases demonstrate that the ECtHR's Article 3 analysis is unconcerned with whether abortion is lawfully accessibly in the State. Rather, the ECtHR focuses on the vulnerability of the applicant and whether she suffered inhuman and/or degrading treatment.

In R. R. $v$ Poland, the applicant had a scan at 18 weeks into the pregnancy which indicated that her fetus was likely to be suffering from an abnormality. She was repeatedly denied genetic testing to confirm the diagnosis. By the time a diagnosis of fetal abnormality was confirmed, it was too late to obtain a legal abortion. She subsequently gave birth to a baby girl with Turner syndrome. ${ }^{94}$ The applicant claimed she was subjected to inhuman and degrading treatment under Article 3. She claimed that she was treated in a dismissive, contemptuous manner by doctors who criticised her for requesting prenatal tests and for considering an abortion. ${ }^{95}$ She argued this was an intentional denial of care to prevent her from having an abortion.

P. and S. $v$ Poland concerned a minor (the first applicant), who became pregnant as a result of rape. ${ }^{96}$ She and her mother, (the second applicant), agreed that she should have an abortion, which is lawful in Poland if the pregnancy results from rape. However, the applicants' numerous attempts to obtain an abortion were denied. The mother was told

\footnotetext{
${ }^{91}$ Attorney General v X [1992] IESC 1, [1992] 1 IR 1; Case C-159/90 Society for the Protection of Unborn Children Ireland Ltd. v Grogan [1991] ECR 4685; Open Door and Dublin Well Woman v Ireland App no 14234/88 (ECHR, 29 October 1992); F De Londras and M Enright, Repealing the 8th: Reforming Irish Abortion Law (Bristol Policy Press 2018); F De Londras, 'Constitutionalizing Fetal Rights: A Salutary Tale from Ireland' (2015) 22(2) Michigan Journal of Gender and Law 234.

92 R. R. v Poland App No 27617/04 (ECHR, 26 May 2011).

93 P. and S. v Poland App No 57375/08 (ECHR, 30 October 2012). The ECtHR also found a breach of Art 8 in this case.

${ }_{94}$ Turner syndrome is a genetic disorder that affects about 1 in every 2,000 baby girls. A girl with Turner syndrome only has one normal X sex chromosome, rather than the usual two XX sex chromosomes. Females with Turner syndrome often have a wide range of symptoms and some distinctive characteristics such as shortness and underdeveloped ovaries. See NHS, 'Turner Syndrome', https://www.nhs.uk/conditions/turner-syndrome/ accessed 22 February 2018.

${ }_{95}$ R. R. v Poland App No 27617/04 (ECHR, 26 May 2011) [145].

96 P. and S. v Poland App No 57375/08 (ECHR, 30 October 2012).
} 
by doctors that she should 'get her daughter married', ${ }^{97}$ and was called a 'bad mother' ${ }^{98}$ The hospital issued a press release informing journalists of the case and it became national news; the first applicant was visited by a priest and an anti-abortion activist while in hospital; and she also received text messages from anti-abortion activists to persuade her not to have an abortion. ${ }^{99}$ Subsequently, the first applicant was placed in a juvenile centre, but on appeal she was released back to her mother. Eventually, the second applicant contacted the Ministry for Health who arranged for the applicants to be driven in secrecy to Gdańsk, 500 kilometres away from their home, where the first applicant had an abortion in a public hospital. The applicants felt that this abortion was done in a 'clandestine manner despite the abortion being lawful'.100 When the applicants arrived home, they discovered that information about their journey had been disseminated on the internet by the Catholic Information Agency.

In both $R . R . v$ Poland and $P$. and $S . v$ Poland the ECtHR offered a much deeper analysis of the applicants' circumstances than offered in the earlier decisions of $A$., $B$. and C. $v$ Ireland and Tysią $v$ Poland, elucidating what is necessary to establish a violation of Article 3 where there is ineffective access to abortion.

In both R. R. v Poland and P. and S. $v$ Poland, the ECtHR drew on its long line of jurisprudence as outlined in section III (B) above. It referred to, inter alia, the relevance of physical and mental effects; ${ }^{101}$ the sex, age, and state of health of the victim; ${ }^{102}$ the length of suffering; and feelings of fear, anguish, and inferiority capable of humiliating or debasing the victim. ${ }^{103}$ Moreover, and of relevance in the abortion context, the ECtHR expressly confirmed that acts and omissions in the field of healthcare policy could in certain circumstances engage State responsibility under Article 3 'by reason of their failure to provide appropriate medical treatment.'104

The ECtHR's consideration of the specific circumstances of each case merits further analysis. In $R . R . v$ Poland the ECtHR highlighted that despite having a scan confirming the likelihood of an abnormality, the process for accessing genetic testing was 'marred by procrastination, confusion and lack of proper counselling and information'.105 By the time she received the results, it was too late for her to have an abortion. Doctors treated her 'shabbily', resulting in her humiliation. ${ }^{106}$ Consequently, the ECtHR held her suffering met the minimum threshold for a breach of Article 3 of the ECHR. ${ }^{107}$

Three points should be flagged at this juncture. First, the ECtHR arguably used the

\footnotetext{
97 P. and S. v Poland App No 57375/08 (ECHR, 30 October 2012) [13].

98 P. and S. v Poland App No 57375/08 (ECHR, 30 October 2012) [20].

99 P. and S. v Poland App No 57375/08 (ECHR, 30 October 2012) [17].

100 P. and S. $v$ Poland App No 57375/08 (ECHR, 30 October 2012) [41].

101 P. and S. v Poland App No 57375/08 (ECHR, 30 October 2012) [158]; R.R. v Poland App no 27617/04 (ECHR, 26 May 2011) [149].

102 P. and S. v Poland App No 57375/08 (ECHR, 30 October 2012) [90]; R. R. v Poland App no 27617/04 (ECHR, 26 May 2011) [148].

103 P. and S. $v$ Poland App No 57375/08 (ECHR, 30 October 2012) [92]; R. R. v Poland App No 27617/04 (ECHR, 26 May 2011) [159].

${ }^{104}$ R. R. v Poland App No 27617/04 (ECHR, 26 May 2011) [152] P. and S. v Poland App No 57375/08 (ECHR, 30 October 2012); VC v Slovakia, App no 18968/07 (ECHR, 8 November 2011) [106-120].

105 P. and S. $v$ Poland App No 57375/08 (ECHR, 30 October 2012) [153].

106 R. R. v Poland App No 27617/04 (ECHR, 26 May 2011) [160].

107 R. R. v Poland App No 27617/04 (ECHR, 26 May 2011) [161], [162].
} 
threshold test in $A, B, C$ as a smokescreen to tactically avoid finding a violation of Article 3 because it would, in effect, be declaring Ireland's abortion legislation incompatible with the ECHR. The ECtHR may have perceived it politically less risky to find a violation of Article 3 in $R R v$ Poland and $P$ and $S v$ Poland given that abortion was legally available in Poland but inaccessible in practice. However, the fact that the ECtHR did not focus on the legality of abortion within Poland in these cases is important as it leaves the door open for the ECtHR to incrementally broaden its position on abortion rights in future case law. This approach is desirable as Article 3 is absolute in nature and violations of Article 3 cannot be justified by reference to domestic law.

Second, the ECtHR described $R$. R.'s suffering as 'aggravated' by the fact that she was legally entitled to such diagnostic tests as a matter of domestic law in the State. 108 This indicates that the legality of the testing was not the sole or necessary factor for proving a violation of Article 3.

Third, the crucial factor in the ECtHR's reasoning in both cases was that the applicants were in situations of great vulnerability. ${ }^{109}$ This aligns with the views of the HRComm in both Mellet and Whelan. In RR, the ECtHR noted that the applicant: 'like any other pregnant woman in her situation, was deeply distressed by information that the foetus could be affected with some malformation.'110 In $P$ and $S$, The ECtHR stated the 'cardinal importance' of the fact that the applicant was only 14, her pregnancy was a result of rape, 111 and she was in a position of 'great vulnerability'.112 The ECtHR also stated that medical and religious authorities 'not only failed to provide protection to her, having regard to her young age and vulnerability, but further compounded the situation'. ${ }^{113}$ The ECtHR was struck by the fact the authorities instituted a criminal investigation against the first applicant on charges of unlawful intercourse when she should have been considered a victim of sexual abuse. ${ }^{114}$ In short, the ECtHR stated that there was no proper regard to her 'vulnerability and young age and her own views and feelings'. ${ }^{115}$ Thus, in both cases, the fact that abortion was legally provided for within Poland was ostensibly not a legal precondition for finding a violation of Article 3. We submit that this approach fits doctrinally with the absolute nature of Article 3. In fact, we argue that the lack of legally available abortion services in cases of FFA strengthens any claim under Article 3 . When a woman is denied an abortion, her suffering is made no more tolerable to her in the knowledge that the denial conformed with domestic law. As argued by the applicant in Mellet, the criminalization of abortion stigmatizes a woman's actions and person, serving as a separate source of severe emotional pain. ${ }^{116}$ This point is expanded upon in section IV below. R. $R$. and $P$ and $S$ are therefore important because by setting to one side the issue of whether abortion services are provided for in law, it paves the way for the ECtHR to declare in future cases that a prohibition of abortion is incompatible with Article 3 ECHR.

\footnotetext{
108 R. R. v Poland App No 27617/04 (ECHR, 26 May 2011) [160].

${ }^{109}$ R. R. v Poland App No 27617/04 (ECHR, 26 May 2011) [159].

110 R. R. v Poland App No 27617/04 (ECHR, 26 May 2011) [159].

${ }^{111}$ R. R. v Poland App No 27617/04 (ECHR, 26 May 2011) [161].

112 R. R. v Poland App No 27617/04 (ECHR, 26 May 2011) [162].

113 P. and S. $v$ Poland App No 57375/08 (ECHR, 30 October 2012) [164].

114 P. and S. v Poland App No 57375/08 (ECHR, 30 October 2012) [165].

115 R. R. v Poland App No 27617/04 (ECHR, 26 May 2011) [166].

116 Human Rights Committee, Amanda Jane Mellet $v$ Ireland, 9 June 2016, UN Doc CCPR/C/116/D/2324/2013, [5.4].
} 


\section{E. The Future of Article 3 Claims}

The ECtHR has not yet delivered a judgment considering whether denial of abortion in circumstances of FFA violates the ECHR. ${ }^{117}$ However, if such circumstances came before the ECtHR (for example, involving states such as Malta, Andorra, or Northern Ireland where abortion is not lawfully and/or practically available in circumstances of FFA), 118 we argue that a very strong case could be made that this would constitute a violation of Article 3 for three reasons.

First, R. R. $v$ Poland and P. and S. $v$ Poland confirm that omissions on the part of the State including non-provision of medical care could constitute violations of Article 3 dependent on the circumstances arising. Hence, the denial of an abortion falls within the range of issues that could be deemed a violation of Article 3.

Second, an applicant could make a strong case that denial of an abortion in cases of FFA amounts to a violation of Article 3 ECHR. All options open to such an applicant terminating the pregnancy illegally, travelling abroad to terminate the pregnancy, or carrying a doomed pregnancy to term - would likely result in inhuman or degrading treatment and should consequently be recognised as a human rights violation. Procuring an illegal abortion (for example, by purchasing pills on the internet) - could expose the woman to risks to her life and/or health as it would be carried out without medical supervision. She is likely to fear seeking counselling and/or aftercare if there are any complications. She would also have to undertake the risks of criminal charges being brought against her, and the corresponding lack of information available and stigma associated with carrying out an illegal act. The second option - procuring an abortion abroad - could result in significant cost and difficulties in securing time off from employment and/or caring responsibilities. She would have to undergo an invasive medical procedure in a foreign environment, possibly without a support structure; and may have to leave the fetus' remains behind. Similarly, she is likely to suffer the stigma associated with the criminalisation of abortion, and the consequent lack of information, counselling and/or aftercare. These two options, as well as the third option of carrying a doomed pregnancy to term, would likely result in 'intense physical and mental suffering' and arouse feelings of fear, anguish, inferiority, humiliation and/or debasement. ${ }^{119}$ It is

\footnotetext{
117 D v. Ireland, App no 26499/02, June 272006 concerned abortion access in cases of FFA, however, the complaint was held inadmissible by the ECtHR which found that the applicant had failed to exhaust domestic remedies.

118 World Abortion Laws www.worldabortionlaws.com accessed 22 February 2018. It should also be noted that at present the Republic of Ireland does not allow for abortions in cases of FFA. However, at the time of writing (2 October 2018), the Oireachtas is considering the adoption in legislation which would provide for abortion in such circumstances.

119 CEDAW recently criticised Northern Irish abortion law, which does not provide abortion in cases of FFA and noted: "the great harm and suffering resulting from the physical and mental anguish of carrying an unwanted pregnancy to full term, especially in cases of...severe foetal impairment, particularly FFA. The situation gives NI women three deplorable options: (a) undergo a torturous experience of being compelled to carry a pregnancy to full term; (b) engage in illegal abortion and risk imprisonment and stigmatisation; or, (c) undertake a highly stressful journey outside NI to access a legal abortion. Women are thus torn between complying with discriminatory laws that unduly restrict abortion or risk prosecution and imprisonment." Committee on the Elimination of Discrimination Against Woman, 'Report of the inquiry concerning the United Kingdom of Great Britain and Northern Ireland under article 8 of the Optional Protocol to the Convention on the Elimination of All Forms of Discrimination against Women' CEDAW/C/OP.8/GBR/1 (19 July 2017) [81]. The Council of Europe's Commissioner for Human Rights has
} 
therefore likely that the denial of an abortion in cases of FFA qualifies as 'inhuman or degrading treatment' as per the ECtHR's jurisprudence.

Third, the ECtHR has already recognized that denying a woman autonomy over her body and reproductive choices can amount to an Article 3 violation. In the context of forced sterilization, the ECtHR noted that it 'was liable to arouse in [the women] feelings of fear, anguish and inferiority and to entail lasting suffering', 120 and that the doctors' interference with the applicants' ability to have children deprived them of an important life choice, leading to depression, the deterioration of their personal relationships, and the loss of status in their communities. ${ }^{121}$ The personal and social consequences that the ECtHR noted in this context, such as depression and social isolation, may also arise in situations when women are denied an abortion, especially in contexts where abortion is heavily restricted and where attempting to access abortion for any reason is highly stigmatized. 122

Fourth, the focus on vulnerability in both cases is significant. We argue that the decision of $R . R . v$ Poland is generalizable to any pregnant woman whose fetus has a malformation or FFA. ${ }^{123}$ The ECtHR expressly stated that R.R. was in a position of 'great vulnerability' as 'like any other pregnant woman in her situation, she was deeply distressed by information that the foetus could be affected with some malformation'.124 The ECtHR also noted that she had to endure 'weeks of painful uncertainty concerning the health of the foetus'. ${ }^{125}$ As noted, such vulnerability and fear would be exacerbated for a pregnant woman with a FFA who wanted an abortion but was prohibited by law.

For these reasons, should a case concerning denial of abortion arise in the circumstances of a FFA, the scene is set for the ECtHR to take the final step and explicitly find a violation of Article 3 irrespective of whether abortion in such circumstances is lawfully available within the respective state. The alternative would be for the ECtHR to use the threshold required for Article 3 to avoid deciding on this issue. We argue that would be a difficult position for it to maintain, as all recent decisions of the ECtHR indicate

\footnotetext{
also highlighted that ' $[t]$ he health and human rights implications of these [restrictive abortion regimes] are acute... the feelings of isolation, fear, humiliation and stigmatisation that these laws often produce, can have a broad range of physical, psychological, financial and social impacts on women, with implications for their health and well-being." Council of Europe, Commissioner for Human Rights, 'Issue Paper: Women's sexual and reproductive health and rights in Europe' (December, 2017) < https://rm.coe.int/women-s-sexualand-reproductive-health-and-rights-in-europe-issue-pape/168076dead $>$ accessed 27 February 2018. In relation to Ireland, he noted the 'severe mental suffering that the denial of abortion services causes to the pregnant woman in cases of...fatal foetal abnormality.' Nils Muižnieks, Commissioner for Human Rights of the Council of Europe, 'Report following his visit to Ireland 22-25 November 2016' (27 March 2017) CommDH (2017)8 [91].

${ }^{120}$ NB v. Slovakia App no 29518/10 (ECHR, 12 June 2012) [80]; VC v Slovakia, App no 18968/07 (ECHR, 8 November 2011) [118].

${ }^{121}$ VC v Slovakia, App no 18968/07 (ECHR, 8 November 2011) NB v. Slovakia App no 29518/10 (ECHR, 12 June 2012); IG and others v Slovakia App no 15966/04 (ECHR, 13 November 2012).

${ }^{122}$ A Zureick, '(En)gendering Suffering: Denial of Abortion as a Form of Cruel, Inhuman, or Degrading Treatment' (2015) 38(1) Fordham International Law Journal 99.

123 The use of the concept of vulnerability is not without its problems. However, a detailed discussion is outside of the scope of this paper. See L Peroni and A Timmer, 'Vulnerable groups: The promise of an emerging concept in European Human Rights Convention Law' (2013) 11(4) International Journal of Constitutional Law 1056.

${ }_{124}$ R. R. v Poland App No 27617/04 (ECHR, 26 May 2011) [159].

125 R. R.v Poland App No 27617/04 (ECHR, 26 May 2011) [159].
} 
it is on the cusp of broader recognition in this context. In addition, the right to abortion in cases of FFA has been recognised by the HRComm and other international TMBs. To take a different view would leave the ECtHR out of sync with the general position in international law, and such divergence would also warrant a justification which would be difficult to provide given that the ECHR has made it clear that international law should be taken into account in interpreting the ECHR. It would also ignore the clear European consensus in favour of legalising abortion in circumstances of FFA. The HRComm's views in Mellet and Whelan can provide a vital bridge for the ECtHR to continue broadening its jurisprudence, transcend its traditional avoidance strategy, ${ }^{126}$ and take a firmer stance on access to abortion in cases in Article 3 and FFA.

The following two sections directly address these points. Section IV shows what the HRComm position as set out in Mellet/Whelan is; and section V puts forward a broader normative and legal case for cross-fertilisation in this context.

\section{ABORTION RIGHTS IN CASES OF FATAL FETAL ABNORMALITY: THE HUMAN RIGHTS COMMITTEE POSITION UNDER ARTICLE 7 ICCPR}

The recent decisions of Mellet $v$ Ireland (June 2016) ${ }^{127}$ and Whelan $v$ Ireland (June 2017) ${ }^{128}$ represent the HRComm's most forthright decisions concerning access to abortion to date. The facts of Mellet were as follows: During her $21^{\text {st }}$ week of pregnancy the complainant was informed at the Rotunda Hospital in Dublin that the fetus she was carrying would die in utero or shortly after birth. Neither the hospital nor the State provided her with any information or assistance to arrange an abortion in another jurisdiction. With the help of a family planning organisation, she travelled to Liverpool Women's Hospital, where she gave birth to a stillborn baby girl. Still feeling weak and bleeding, she travelled back to Dublin, only 12 hours after the delivery, as she could not afford to remain in the UK. ${ }^{129}$ The complainant did not receive any aftercare at the Rotunda Hospital. She suffered from ongoing complicated grief and unresolved trauma and said that she would have been able to better accept her loss if she had not had to endure the pain and shame of travelling abroad.

Ms Whelan's circumstances were strikingly similar to Ms Mellet's. The fetus she was carrying also had a fatal abnormality and she was not provided with information on accessing abortion services in the UK. She also faced significant financial and practical difficulties in travelling to the UK. She had to leave the fetal remains in the UK which were subsequently delivered to her. She did not receive any support upon returning to Ireland while suffering from complicated grief and feelings of isolation. In respect of both women,

\footnotetext{
${ }^{126}$ F De Londras and K Dzehtsiarou 'Managing judicial innovation in the European Court of Human Rights' (2015) 15(3) Human Rights Law Review 523.

127 Human Rights Committee, Siobhán Whelan v Ireland, 12 June 2017, UN Doc CCPR/C/119/D/2425/2014. 128 Human Rights Committee, Amanda Jane Mellet $v$ Ireland, 9 June 2016, UN Doc CCPR/C/116/D/2324/2013.

129 The complainant said that they spent 3,000 EUR in total, including the 2,000 EUR fee they paid for the procedure in the UK.
} 
the HRComm found that Ireland violated Articles 7,130 17,131 and 26 of the ICCPR. ${ }^{132}$ Our analysis for the purposes of this paper focuses solely on the Article 7 claim.

In finding a violation of Article 7 in both cases, the HRComm took a similar approach to the ECtHR decisions of P. and S. $v$ Poland and R.R.v Poland, by focusing on the vulnerability of the pregnant women. In both Mellet and Whelan, the HRComm held that the complainants' physical and mental anguish had been exacerbated by: (i) not being able to continue receiving medical care and health insurance coverage for treatment from the Irish health care system; (ii) the need to choose between continuing a non-viable pregnancy or travelling to another country while carrying a dying fetus, at personal expense and separated from family support, and to return while not fully recovered; (iii) the shame and stigma associated with the criminalization of abortion of a fatally ill fetus; (iv) the fact of having to leave the fetus' remains behind; and (v) the State's refusal to provide necessary and appropriate post-abortion and bereavement care. The HRComm found that many of these experiences could have been avoided if the complainants had not been prohibited from terminating their pregnancies in the familiar environment of their own State. It considered that the complainants' suffering was further aggravated by the obstacles faced in receiving needed information about appropriate medical options from known and trusted medical providers.

The HRComm found a violation of Article 7, notwithstanding the fact that abortion in cases of FFA is not provided for in Irish legislation. This accords with the absolute nature of Article 7, and with the rule in Article 26 of the VCLT that domestic laws cannot justify a violation of international law. In the following sections, we will advocate that these views provide a tipping point for the ECtHR to take a similar stance.

\section{THE CASE FOR CROSS FERTLISATION: MELLET AND WHELAN AS A TIPPING POINT FOR ACTION?}

As aforementioned, although the ECtHR's jurisprudence on abortion rights has broadened in recent years, it has not yet found a violation of Article 3 where abortion is not legally provided for in the relevant State. ${ }^{133}$ This may well be because it is conscious that its decisions are directly binding upon States and its existence and power relies on their support. However, the views of the HRComm in Mellet and Whelan could provide a vital tipping point for the ECtHR to move from its traditional position of self-restraint to expressly acknowledge a right to access abortion in cases of FFA. This is because (i) the

130 This article provides that 'No one shall be subjected to torture or to cruel, inhuman or degrading treatment or punishment. In particular, no one shall be subjected without his free consent to medical or scientific experimentation.'

131 This article provides that '(i) No one shall be subjected to arbitrary or unlawful interference with his privacy, family, home or correspondence, nor to unlawful attacks on his honour and reputation. (ii)Everyone has the right to the protection of the law against such interference or attacks.'

132 This article provides that 'All persons are equal before the law and are entitled without any discrimination to the equal protection of the law. In this respect, the law shall prohibit any discrimination and guarantee to all persons equal and effective protection against discrimination on any ground such as race, colour, sex, language, religion, political or other opinion, national or social origin, property, birth or other status.'

${ }^{133}$ As noted above, the ECtHR was asked to decide on access to abortion in cases of FFA in $D$ v. Ireland, App No. 26499/02 (ECHR 28 June 2006). However, it held that the applicant D's case was inadmissible due to failure to exhaust domestic remedies. 
views in Mellet and Whelan on a violation of Article 7 do not represent a significant departure from the ECtHR's recent case law; and (ii) the ECtHR can use other provisions of international law to bolster its decisions, as it has done many times previously.

A step in the direction of Mellet and Whelan would not be as controversial as it might seem at first sight. First, in section III above, we identify a trend in the gradual broadening of the ECtHR's Article 3 jurisprudence concerning abortion rights.

Second, the reasoning in Mellet and Whelan is similar to the ECtHR's reasoning in R. R. $v$ Poland and P. and S. $v$ Poland. In all four cases, the domestic legality of abortion was not presented by the HRComm/ECtHR as a relevant consideration to finding a violation of Article 7 ICCPR/ Article 3 ECHR. Instead, the focus was on the vulnerability of the woman in question. Moreover, as discussed in section III, it is highly likely that the mental and physical suffering associated with the illegality of abortion services in cases of FFA falls within the ECtHR's definition of cruel, inhumane, and degrading treatment as per Article 3 ECHR. Thus, the ECtHR would not be departing from its own established case law by making such a finding.

Third, the Mellet and Whelan decisions do not explicitly set out a broader right of access to abortions and thus are not radically different from the approach of the ECtHR. ${ }^{134}$ Although the Mellet and Whelan decisions referred to circumstances which applied to all women in Ireland at that time who wished to have an abortion - such as lack of information about overseas abortion providers and the expense and isolation of travelling for an abortion - significant emphasis was placed on the fact that these conditions were exacerbated by the complainants' non-viable pregnancies. In his concurring individual opinion in Mellet, the late Sir Nigel Rodley added that Ireland's refusal to allow for abortions even for FFA could not be justified as being for the protection of the (potential) life of the fetus. He further pointed out that not only had Article 7 been violated cumulatively, but it was also violated by the very requirement that a pregnant woman had to carry a doomed pregnancy to term. ${ }^{135}$ The limited nature of the finding as applicable only in cases of FFA also makes it less likely to be as controversial as it might have been should it have found a right to access abortion in broader circumstances.

Fourth, and relatedly, a movement in the direction of the HRComm would not be as politically unpalatable as it might seem as it is no longer the case that restrictive abortion regimes can be said to truly represent the 'profound moral values'136 of the populations of the affected States. For example, in the Irish context, in June 2017, 89\% of the Citizens' Assembly recommended abortion access be available in cases of fetal

\footnotetext{
134 That is not to say that Mellet and Whelan could not be used in future to argue for a broader right to abortion. According to F De Londras, the decision also at least implies, and the concurring opinions establish, that criminalisation of abortion per se is a violation of the ICCPR. See F De Londras, 'Fatal Fetal Abnormality, Irish Constitutional Law and Mellet v Ireland' (2016) 24(4) Medical Law Review 591.

135 R Cook, 'Sir Nigel Rodle's Insights on the Feminist Transformation of the Right of Conscience', (2018) 40(2) Human Rights Quarterly 255.

136 This was the reasoning offered by the ECtHR for non-interference with Ireland's abortion policy in $A, B$ and $C$ v Ireland App no 25579/05 (ECHR 16 December 2010) [226] where it stated that '...the Court finds that the impugned restrictions in the present case... were based on profound moral values concerning the nature of life which were reflected in the stance of the majority of the Irish people against abortion during the 1983 referendum and which have not been demonstrated to have changed significantly since then.'
} 
abnormality where the fetus is likely to die either before or shortly after birth. ${ }^{137}$ This corresponds to views in the general population at that time as an Amnesty International/Red C poll taken in October 2017 indicated that 81\% supported women having access to abortion in cases of FFA. ${ }^{138}$ Indeed, there appears to be a more general trend in public opinion towards recognising abortion access in Ireland - as aforementioned, $66.4 \%$ of the electorate voted to repeal Art 40.3 .3 of the Constitution and allow the Oireachtas (Irish Parliament) to legislate for abortion services in Ireland. ${ }^{139}$

Fifth, the ECtHR has already warned States that they are outside of the emerging consensus on access to abortion, and may thus be preparing the ground to find a violation of the ECtHR in a future case concerning strict abortion regimes. ${ }^{140}$ Indeed, Zurieck has argued that the finding of a violation of Article 3 in $R . R . v$ Poland and P. and S. $v$ Poland may have reflected the ECtHR's frustration with Poland for not changing the domestic framework after the decision in Tysiąc $v$ Poland. ${ }^{141}$ In future cases, the ECtHR could rely on the European consensus in favour of abortion access in cases of FFA to find that such a right is also provided for under Article 3 ECHR. ${ }^{142}$

The above arguments are supported by the practical, doctrinal, consideration that the ECtHR has repeatedly affirmed that the ECHR should be interpreted light of 'any relevant rules of international law'. ${ }^{143}$ The views of the HRComm qualify as 'relevant rules' because (i) the HRComm has been mandated to provide 'authoritative'144and

137 The Citizens' Assembly is a body comprising of 99 citizens, which was established by the Irish government in 2016 to consider important Irish political issues. One of these issues was Art 40.3.3 of the Constitution (the so-called Eighth amendment), which protects the right to life of the unborn. See The Citizens' Assembly, The Eighth Amendment of the Constitution: Final Report (2017), 8.

138 The Amnesty International/Red C Poll was conducted between 16-20th October 2017 and polled 1,000 adults in Ireland. The sample size was controlled by age, gender, socio-economic status and region in order to ensure a fully representative sample. The poll also indicated that $60 \%$ of respondents believed that women should have access to abortion on request, either outright or within specific gestational limits. See Amnesty International, 'Amnesty International/ Red C Poll Reveals 60\% Support Access to Abortion on Request' https://www.amnesty.ie/itstimepoll/ accessed 22 February 2018.

139 See, Niamh Towey and Dan Griffin, Ireland votes Yes in abortion referendum (Irish Times, 26th May 2018) available at https://liveblog.irishtimes.com/d1719622b8/Ireland-votes-Yes-in-abortionreferendum/

${ }^{140}$ E Wickes, 'International Trends in the Recognition of Abortion Rights' in CM Buckey, A Donald, and P Leach (eds), Towards Convergence in Human Rights Law: Approaches of Regional and International Systems, (Brill 2017) 103.

141 A Zureick, '(En)gendering Suffering: Denial of Abortion as a Form of Cruel, Inhuman, or Degrading Treatment' (2015) 38(1) Fordham International Law Journal 99.

142 World Abortion Laws www.worldabortionlaws.com accessed 22 February 2018.

143 Article 31(3)(c) VCLT; Al-Adsani v United Kingdom App no 35763/97 (ECHR, 21 November 2001) [55]; Loizidou $v$ Turkey App no 15318/89 (ECHR, 23 March 1995) [43]; Al Jedda v United Kingdom App no 27021/08 (ECHR, 7 July 2011) [76]; Bankovic v Belgium App no 52207/99 (ECHR, 12 December 2001)[5558]; Golder v. the United Kingdom App no 4451/70 (ECHR, 21 February 1975) [29]; Johnston and Others v. Ireland App no 9697/82 (ECHR, 18 December 1986) [51]; Mamatkulov and Askaraov v Turkey App no 46827/99 (ECHR. 4 February 2005) [111].

144 Human Rights Committee, General Comment 33, 'Obligations of States parties under the Optional Protocol to the International Covenant on Civil and Political Rights', 25 June 2009, UN Doc CCPR/C/GC/33 [14]. 
'determinative'145 interpretations of the ICCPR;146 (ii) the views of the HRComm exhibit most of the characteristics of a judicial decision, follow a judicial method of operation, and are issued in a judicial spirit; 147 (iii) members of the HRComm are persons of high moral character and recognized competence in the field of human rights, ${ }^{148}$ rendering their views very persuasive. Most, if not all of them, are experts in international law, and thus their views are a subsidiary source of international law. ${ }^{149}$ It is therefore unsurprising that the ECtHR has frequently relied upon the views of the HRComm. ${ }^{150}$ Indeed, the ECtHR has also been more receptive to the ICCPR than to any other treaty in its decisions. ${ }^{151}$

There are a number of criteria which increase the likelihood that the ECtHR will take a particular rule of international law into account as an interpretative source. We argue that all these criteria are satisfied in respect of the HRComm's views concerning Article 7 ICCPR. First, the ECtHR is more likely to refer to a particular treaty in its reasoning if the respective treaty is widely ratified and if the State implicated in a particular case is a party to it. All 47 Council of Europe Member States are party to the ICCPR, including the United Kingdom, Andorra, Malta and Poland, the CoE states with the strictest abortion regimes. ${ }^{152}$ By becoming a party to the ICCPR, CoE Member States have undertaken to ensure to all individuals within its territory or subject to its jurisdiction the rights recognized in the ICCPR. ${ }^{153}$ Thus, the ICCPR - and indeed, other treaties have equal binding force in international law on States as the ECHR does. ${ }^{154}$ Hence, pragmatically, it is easier for States Parties to abide by their international law obligations under the separate treaties if the approaches of the ECtHR and HRComm align.

Secondly, the ECtHR has been more willing to refer to the ICCPR/HRComm where

\footnotetext{
${ }^{145}$ Human Rights Committee, General Comment 33, 'Obligations of States parties under the Optional Protocol to the International Covenant on Civil and Political Rights', 25 June 2009, UN Doc CCPR/C/GC/33 [11].

${ }^{146} \mathrm{JE}$ Alvarez has described them as 'quasi-judicial'. See JE Alvarez, International Organisations as LawMakers (Oxford University Press 2006), Chapter 6.

147 Human Rights Committee, General Comment 33, 'Obligations of States parties under the Optional Protocol to the International Covenant on Civil and Political Rights', 25 June 2009, UN Doc CCPR/C/GC/33 [11].

148 Art 28, 1966 International Covenant on Civil and Political Rights 999 UNTS 171.

149 'Human Rights Committee: Membership'

http://www.ohchr.org/EN/HRBodies/CCPR/Pages/Membership.aspx accessed 22 February 2018; Article 38(1)(d), 1946 Statute of the International Court of Justice.

150 Py v France App no 66289/01 (ECHR, 1 November 2005); TH and SH v Finland App No 19823/92 (ECHR, 9 February 1993); Kurt $v$ Turkey App No 15/1997/799/1002 (ECHR, 25 May 1998); Mamatkulov and Abdurasulovic v Turkey App Nos 46827/99, 46951/99 (ECHR, 6 February 2003); Mamatkulov and Askarov $v$ Turkey App Nos 46827/99, 46951/99 (ECHR, 4 February 2005).

${ }^{151}$ M Forowicz, The Reception of International Law in the European Court of Human Rights, (Cambridge University Press 2010), 175.

152 The legal position in Northern Ireland is different from the remainder of the UK because the Abortion Act 1967 does not apply in Northern Ireland. Instead, abortion is illegal in Northern Ireland, and still governed by s. 58 and s. 59 of the Offences Against the Person Act 1861.

153 This is not to say that the Council of Europe - or consequently the ECtHR - is bound by the ICCPR, but rather the individual Contracting States of the ECHR have a duty under international law to comply with their treaty obligations in good faith. They cannot invoke domestic law (as Ireland tried to do in the Mellet and Whelan complaints, discussed below) as a justification for failure to comply with its international law obligations. See Art 27, VCLT.

${ }^{154}$ Such as the CEDAW; CRC; ICESCR.
} 
there is similarity between the content of the specific ICCPR right(s) and ECHR right(s). ${ }^{155}$ Both treaties prohibit torture or inhuman, or degrading treatment (Article 7 ICCPR and Article 3 ECHR). The ECtHR and the HRComm have both found that because of the right's absolute nature, a State may not seek to justify its conduct with reference to a need to balance the rights protected under it with the rights of others. ${ }^{156}$ Furthermore, the wording of Article 3 ECHR and Article 7 ICCPR is almost identical. More broadly, both the ICCPR and ECHR contain civil and political rights, are based on the Universal Declaration of Human Rights, and share the same fundamental overarching principles. ${ }^{157}$

Thirdly, the ECHR has been more willing to refer to the ICCPR/ HRComm where the ICCPR provides more extensive protection to the claimant. 158 This is satisfied by the views of the HRComm on abortion access, which has traditionally been more willing than the ECtHR to find a State's restrictive abortion regime in violation of the ICCPR. ${ }^{159}$ A strong case for cross-fertilisation can be put forward based on the obligations as set out below to interpret the ECHR in a way which respects general international law.

Thus we argue that the ECtHR should align itself with the HRComm's views in this context because (i) the approach of the ECtHR has traditionally been problematic, and the HRComm's approach is preferable, as set out in sections II and III of this paper; (ii) the ECtHR's recent jurisprudence on Article 3 and abortion rights is broadening, as set out in section III; (iii) a movement in the direction of the HRComm would not be as politically controversial as it might seem, as set out in this section; and (iv) the ECtHR has frequently used international law as an interpretative tool, as also set out in this section.

Moreover, as discussed above, one way for a court to move from a position of selfrestraint to a broader approach, whilst also reducing the risk to its reputation of doing so, is by citing other TMBs/international courts who have adopted a similar position. The ECtHR could use the HRComm's view to bolster and legitimate a finding that denial of abortion in cases of FFA is a violation of Article 3. Such a decision could be framed by the ECtHR as being inspired by the wider international trend in favour of recognising the significant impact of a failure to provide abortion access on the human rights of women, as represented by the views of the HRComm. In this way, and through cross-fertilisation of norms and dialogue between the HRComm and ECtHR systems, a more coherent system for the development of the prohibition of torture or inhuman and degrading treatment in the context of access to abortion is possible. We thus strongly advocate that if a similar case to Mellet and Whelan were to come before the ECtHR, the ECtHR should be willing to draw on the HRComm's work and find a violation of Article 3 ECHR, regardless of whether

\footnotetext{
155 M Forowicz, The Reception of International Law in the European Court of Human Rights, (Cambridge University Press 2010), 188.

156 UN General Assembly, 'Report of the Special Rapporteur on Torture and other cruel, inhuman and degrading punishment', 5 February 2010, UN Doc A/HRC/13/39/Add.5.

157 A Buyse, 'Echos of Strasbourg in Geneva - the Influence of ECHR Anti-Torture Jurisprudence on the United Nations Human Rights Committee' (2016) 59 Japanese Yearbook of International Law 81, 82.

158 M Forowicz, The Reception of International Law in the European Court of Human Rights, (Cambridge University Press 2010), 362.

159 For example, the HRComm condemned the difficulty for a minor to access a therapeutic abortion in Peru (Human Rights Committee, KL v Peru, 22 November 2005, UN Doc CCPR/C/85/D/1153/2003) and the difficulty for a young girl with a mental impairment, who was pregnant as a result of rape, to access an abortion in Argentina (Human Rights Committee, LMR $v$ Argentina, 28 April 2011, UN Doc CCPR/C/101/D/1608/2007).
} 
abortion is legal in the applicant's State.

\section{CONCLUSION: BEYOND THE ECHR AND TOWARDS A GLOBAL UNDERSTANDING OF ACCESS TO ABORTION IN CASES OF FATAL FETAL ABNORMALITY?}

This article has rejected the dominant view in the literature that the ECtHR is a fruitless avenue for challenging States' restrictive abortion frameworks. We focused on Article 3, rather than the oft-discussed Article 8, and argued that Article 3 provides a significant avenue by which restrictive abortion frameworks can and should be challenged.

In this article, we sought to demonstrate how Article 3's strength can be harnessed through a process of trans-institutional dialogue between the ECtHR and the HRComm whose recent views found that denial of abortion in cases of FFA violates Article 7 ICCPR. We aimed to illustrate how ECtHR jurisprudence on Article 3 has recently shifted, setting the scene for it to engage with the HRComm. We further argued that the views of the HRComm in Mellet and Whelan provide a vital tipping point to move the ECtHR from its traditional pattern of self-restraint in abortion cases to recognizing that denial of abortion in cases of FFA violates Article 3 ECHR.

The arguments made in this article in respect of FFA may have broader applicability in cases where abortion is denied/inaccessible for an individual whose pregnancy is the result of rape. The fact that pregnancy is caused by rape is likely to exacerbate suffering for women denied an abortion as the pregnancy and the potential child remain as a reminder of the rape. This is likely to exacerbate the pregnant person's mental suffering, putting the pregnant person in a vulnerable position. ${ }^{160}$

If the ECtHR were to adopt our views and acknowledge a violation of Article 3 where abortion is denied in cases of FFA (and indeed, by analogy, in cases of rape), this would be a significant achievement for reproductive rights because the ECtHR is perceived to be the most powerful enforcement mechanism of human rights in the world. It can order compensation and there is an international legal obligation to execute its judgments. ${ }^{161}$ Although the judgments of the ECtHR are technically binding only on the

\footnotetext{
${ }^{160}$ The following reports indicated rape and/or FFA as grounds wherein abortion access should be provided for owing to the suffering caused to the pregnant person: (i) Committee on the Elimination of Discrimination Against Woman, 'Report of the inquiry concerning the United Kingdom of Great Britain and Northern Ireland under article 8 of the Optional Protocol to the Convention on the Elimination of All Forms of Discrimination against Women' CEDAW/C/OP.8/GBR/1 (19 July 2017) [81]; (ii) Council of Europe, Commissioner for Human Rights, 'Issue Paper: Women's sexual and reproductive health and rights in Europe' (December, 2017) <https://rm.coe.int/women-s-sexual-and-reproductive-health-and-rights-ineurope-issue-pape/168076dead> accessed 27 February 2018. (iii) Nils Muižnieks, Commissioner for Human Rights of the Council of Europe, 'Report following his visit to Ireland 22-25 November 2016' (27 March 2017) CommDH (2017)8 [91]. The report noted the 'severe mental suffering that the denial of abortion services causes to the pregnant woman in cases of...fatal foetal abnormality.' (iv) Human Rights Council, 'Report of the Special Rapporteur on torture and other cruel, inhuman or degrading treatment or punishment Juan E. Méndez' (2013) A/HRC/22/53 [49-50]; (v) 'CCPR General Comment No. 28: Article 3 (The Equality of Rights Between Men and Women 29 March 2000, CCPR/C/21/Rev.1/Add.10[11].

${ }^{161} \mathrm{~F}$ de Londras and K Dzehtsiarou, Great Debates on the European Convention on Human Rights (Palgrave 2018).
} 
Contracting State concerned, in effect the jurisprudence has an erga omnes effect. This means that all 47 Contracting States are urged to take account of the ECtHR jurisprudence and to draw necessary implications with respect to their own laws and practice. ${ }^{162}$ Domestic courts are thus far more likely to cite ECtHR judgments than jurisprudence relating to other treaties, ${ }^{163}$ and ECtHR decisions are cited beyond the CoE in both domestic and international courts. ${ }^{164}$ Consequently, ECtHR judgments frequently have more of an impact and are more widely publicised than the views of the TMBs, and an explicit recognition of abortion rights in cases of FFA would be a significant development in this respect.

Moreover, trans-institutional dialogue and cross-fertilisation of norms should be encouraged across all TMBs/international courts. Despite the difficulties which can arise as a result of fragmentation, it creates useful fora for interaction across TMBs/international courts. It can lead to a more rigorous development of rights as TMBs/international courts learn from each other and work together to further the shared objective of rights development within a global community. ${ }^{165}$ It can also make law more responsive to societal and/or technological developments. In addition, fragmentation may complement the process of incremental rights development as incremental steps can occur across different bodies in a global system, which can move the law forward more quickly if such bodies engage with and refer to each other. ${ }^{166}$ In the words of the International Law Commission:

[A]ll international law exists in systemic relationship with other law [...] although a tribunal may only have jurisdiction in regard to a particular instrument, it must always interpret and apply that instrument to its normative environment - that is to say 'other' international law. ${ }^{167}$

We have sought to illustrate how positive aspects of fragmentation within international law can complement the process of rights development as it lends more voices to the process, and engagement with these voices helps foster a more rigorous system of human rights protection. As Forowicz argues:

By linking the case law of both bodies [the ECtHR and HRComm], the inception of a concrete dialogue would render the coordination between the institutions more viable and strengthen the protection of the rights enshrined in the ECHR and ICCPR. ${ }^{168}$

\footnotetext{
${ }^{162}$ D McGoldrick, 'A Defence of the Margin of Appreciation and an Argument for its Application by the Human Rights Committee' (2016) 65(1) International and Comparative Law Quarterly 21.

163 This is particularly so in states such as Ireland and the UK that have specific legislation directing courts to take ECtHR decisions into account.

${ }^{164}$ Hussainara Khatoon and Others $v$ Home Secretary State of Bihar (1980) 1 SCC 81 (Supreme Court of India); Filartiga v Pena-Irala 630 F 2d 876 (1980) (US Court of Appeals); Ncube, Tshuma and Ndhlovu v the State (1988) 2 S. Afr. L. Rep. 702 (Zimbabwe Supreme Court).

165 L Helfer and AM Slaughter, 'Toward a Theory of Effective Supranational Adjudication' (1997) 107 Yale Law Journal 273.

${ }^{166}$ L Helfer and AM Slaughter, 'Toward a Theory of Effective Supranational Adjudication' (1997) 107 Yale Law Journal 273, 314-315.

167 International Law Commission, 'Fragmentation of International Law: Difficulties Arising from the Diversification and Expansion of International Law', 13 April 2006, UN Doc A/CN.4/L.682, 212.

${ }_{168} \mathrm{M}$ Forowicz, The Reception of International Law in the European Court of Human Rights, (Cambridge University Press 2010), 189.
} 
The arguments in favour of cross-fertilization and judicial dialogue could also be applied in other contexts. For example, the jurisprudence of the ECtHR concerning deportation of failed asylum-seekers could be significantly enhanced by looking at the jurisprudence of the Inter-American Commission of Human Rights (IACHR). When considering whether a deportation from State A to State B would result in violation of Article 3, the ECtHR takes into account whether the circumstances in State B are attributable to State B. ${ }^{169}$ This is problematic as an individual may not be able to contest deportation where the risk of suffering is attributable to other actors, such as terrorist groups, or where the suffering is caused by a natural disaster, famine, or drought. The IACHR has taken a different approach in its examination of Article XXVI of the American Declaration on the Rights and Duties of Man (protection from cruel, infamous, and unusual punishment) in the context of deportation decisions. In the case of Mortlock $v$ USA it relied heavily on various aspects of the ECHR's approach to Article 3, but it did not take into account whether the circumstances in the receiving State were attributable to that State. ${ }^{170}$ The ECtHR should consider adopting this approach, as it would be more compatible with the ECtHR's general approach to deportation cases (which focuses on the actions of State A, the party to the case who makes the decision to deport), and it would be more compatible with the absolute nature of Article 3 ECHR. ${ }^{171}$ The reasons put forward in this paper in support of increased cross-fertilization could be similarly relied upon by the ECHR to take into account the IACHR's approach to deportation cases.

In sum, we view fragmentation, on balance, as a positive aspect of international law. Increased cross-fertilisation between the ECtHR and the HRComm could lead to dialogue rather than monologue, deliberation rather than gap filling, approaching a problem with more creativity or greater insight, and could enhance the legitimacy of judgments. ${ }^{172}$ The ECtHR has referred to the ICCPR and the views of the HRComm on numerous occasions as a means of interpretation and of harmonising the ECHR with the ICCPR, and we strongly advocate that it should continue to do so in the context of abortion rights.

\footnotetext{
${ }^{169}$ MSS v Belgium and Greece App no 30696/09 (ECHR, 21 January 2011). The CJEU takes a similar approach. See Case C 542/13 M'Bodj v Conseil des Ministres (CJEU, 18 December 2014).

170 Mortlock v USA, Inter-American Commission of Human Rights Report No. 63/08 Case 12.

${ }^{171}$ B Ní Ghráinne, 'Challenges in the Relationship between Internally Displaced Persons and International Refugee Law' (DPhil thesis, University of Oxford).

172 AM Slaughter, 'A Global Community of Courts' (2003) 44(1) Harvard International Law Journal 191.
} 